\title{
Polychemotherapy with Curcumin and Doxorubicin via Biological Nanoplatforms: Enhancing Antitumor Activity
}

\author{
Milad Ashrafizadeh ${ }^{1,2,+}\left(\mathbb{D}\right.$, Ali Zarrabi ${ }^{2,+}+{ }^{-}$, Farid Hashemi ${ }^{3}$, Amirhossein Zabolian ${ }^{4}$, \\ Hossein Saleki ${ }^{4}$ (D), Morteza Bagherian ${ }^{4}$, Negar Azami ${ }^{4}$, Atefe Kazemzade Bejandi ${ }^{4}$, \\ Kiavash Hushmandi ${ }^{5}$, Hui Li Ang ${ }^{6}$, Pooyan Makvandi ${ }^{7, *} \mathbb{D}$, Haroon Khan ${ }^{8}$ and \\ Alan Prem Kumar 6,*(D) \\ 1 Faculty of Engineering and Natural Sciences, Sabanci University, Orta Mahalle, Üniversite Caddesi No. 27, \\ Orhanl, Tuzla, 34956 Istanbul, Turkey; milad.ashrafizadeh@sabanciuniv.edu \\ 2 Sabanci University Nanotechnology Research and Application Center (SUNUM), Tuzla, \\ 34956 Istanbul, Turkey; alizarrabi@sabanciuniv.edu \\ 3 Department of Comparative Biosciences, Faculty of Veterinary Medicine, University of Tehran, \\ Tehran 1419963114, Iran; faridhashemi172@gmail.com \\ 4 Young Researchers and Elite Club, Tehran Medical Sciences, Islamic Azad University, \\ Tehran 1916893813,Iran; ah_zabolian@student.iautmu.ac.ir (A.Z.); h.saleki@student.iautmu.ac.ir (H.S.); \\ morteza1429@gmail.com (M.B.); negarazami77@gmail.com (N.A.); \\ atefe.kazemzade1376@gmail.com (A.K.B.) \\ 5 Department of Food Hygiene and Quality Control, Division of Epidemiology \& Zoonoses, \\ Faculty of Veterinary Medicine, University of Tehran, Tehran 1419963114, Iran; houshmandi.kia7@ut.ac.ir \\ 6 Cancer Science Institute of Singapore and Department of Pharmacology, Yong Loo Lin School of Medicine, \\ National University of Singapore, Singapore 117599, Singapore; e0336095@u.nus.edu \\ 7 Centre for Micro-BioRobotics, Istituto Italiano di Tecnologia, viale Rinaldo Piaggio 34, 56,025 Pontedera, \\ Pisa, Italy \\ 8 Department of Pharmacy, Abdul Wali Khan University, Mardan 23200, Pakistan; \\ haroonkhan@awkum.edu.pk \\ * Correspondence: pooyan.makvandi@iit.it (P.M.); csiapk@nus.edu.sg (A.P.K.); Tel.: +39-392-828-8866 (P.M.); \\ +65-6516-5456 (A.P.K.) \\ + These authors have contributed equally.
}

Received: 3 October 2020; Accepted: 7 November 2020; Published: 11 November 2020

check for updates

\begin{abstract}
Doxorubicin (DOX) is a well-known chemotherapeutic agent extensively applied in the field of cancer therapy. However, similar to other chemotherapeutic agents such as cisplatin, paclitaxel, docetaxel, etoposide and oxaliplatin, cancer cells are able to obtain chemoresistance that limits DOX efficacy. In respect to dose-dependent side effect of DOX, enhancing its dosage is not recommended for effective cancer chemotherapy. Therefore, different strategies have been considered for reversing DOX resistance and diminishing its side effects. Phytochemical are potential candidates in this case due to their great pharmacological activities. Curcumin is a potential antitumor phytochemical isolated from Curcuma longa with capacity of suppressing cancer metastasis and proliferation and affecting molecular pathways. Experiments have demonstrated the potential of curcumin for inhibiting chemoresistance by downregulating oncogene pathways such as MMP-2, TGF- $\beta$, EMT, PI3K/Akt, NF-kB and AP-1. Furthermore, coadministration of curcumin and DOX potentiates apoptosis induction in cancer cells. In light of this, nanoplatforms have been employed for codelivery of curcumin and DOX. This results in promoting the bioavailability and internalization of the aforementioned active compounds in cancer cells and, consequently, enhancing their antitumor activity. Noteworthy, curcumin has been applied for reducing adverse effects of DOX on normal cells and tissues via reducing inflammation, oxidative stress and apoptosis. The current review highlights the anticancer mechanism, side effects and codelivery of curcumin and DOX via nanovehicles.
\end{abstract}


Keywords: doxorubicin; curcumin; chemoresistance; side effect; apoptosis; nanodelivery

\section{Introduction}

The necessity for having a new approach in chemotherapy is due to an emerging phenomenon, known as "chemoresistance" [1]. Triggering apoptosis, DNA damage, mitotic catastrophe, impairing microtubule stabilization and so on are responsible for antitumor activity of chemotherapeutic agents. However, frequent utilization of a specific chemotherapeutic agent is correlated with resistance of cancer cells to apoptosis induction [2,3]. Furthermore, cancer cells can prevent DNA damage following chemotherapy by stimulating molecular pathways involved in DNA repair. Thus, it is quite obvious that a new regime should be recommended for effective chemotherapy of cancer cells.

Increasing evidence demonstrates that phytochemicals, due to their excellent antitumor activity, can be considered as potential agents for coadministration with chemotherapeutic agents in cancer therapy $[4,5]$. Phytochemicals impair proliferation and metastasis of cancer cells, and sensitize cancer cells to apoptosis and DNA damage caused by chemotherapeutic agents [6-8]. This polychemotherapy with natural compounds is of importance in reversing chemoresistance. Interestingly, chemoresistance is not the only challenge in the field of chemotherapy. In order to promote antitumor activity of chemotherapeutic agents, high doses of these agents are applied that substantially enhances side effects on other organs of body. Ototoxicity [9], hepatotoxicity [10], nephrotoxicity [11] and cardiotoxicity [12] are a few of adverse effects of chemotherapeutic agents.

Based on pharmacological activities of natural products such as antioxidant that is of importance for reducing levels of reactive oxygen species (ROS) and a subsequent decrease in side effects of chemotherapeutics, coadministration of phytochemical and chemotherapeutic agents not only promotes antitumor activity and reverses chemoresistance, but also is beneficial in improving side effects $[13,14]$. Further issue that can be addressed is the poor bioavailability of phytochemicals and chemotherapeutic agents. Nanoarchitectures are structures with a size of less than $100 \mathrm{~nm}$ that can be synthesized via different methods [15-17]. Nanoparticles can provide a platform for co-loading of plant derived-natural products and chemotherapeutic agents in effective cancer therapy $[18,19]$.

In the present review, we discuss potential of curcumin as a natural product for being employed in combination chemotherapy with doxorubicin. Potentiating antitumor activity of doxorubicin against cancer cells, reversing chemoresistance and nanocarriers for codelivery of curcumin and doxorubicin are described in this review article based on newly published articles.

\section{Curcumin: Structure and Pharmacokinetics}

As a curcuminoid, curcumin is a bioactive component of rhizome of Curcuma longa and comprises $1.5-3$ weight $(\mathrm{wt}) \%$ of this plant [20]. Turmeric possesses three components including curcumin, bisdemethoxycurcumin and demethoxycurcumin. The most abundant component of turmeric is curcumin [21]. This yellow pigmented powder is derived from rhizome of turmeric via grinding [22]. It is responsible for the yellow color of turmeric and for a long time, this flavoring substance has been widely applied in different regions of Asia for treatment of various disorders [23-26]. The chemical formula of curcumin is n,1,7-bis-(3-hydroxy-4-methoxyphenyl)-1,6-heptadiene-3,5-dione. Structurally, curcumin has two phenyl rings substituted with hydroxyl and methoxyl groups connected via a seven-carbon keto-enol linker $[27,28]$. The first discovered pharmacological activity of curcumin is an antibacterial effect, found in 1949 [29]. Further studies focused on revealing other therapeutic and biological activities of curcumin including antiproliferative [30], antimetastatic [31], antioxidant [32], anti-inflammatory [33], antidiabetic [34], antiangiogenic [35], immunomodulatory [36], antitumor [37], antiatherosclerotic [38] and a lipid lowering effect [39] and regulating blood pressure [40].

However, rapid metabolization of curcumin in body is a major impediment towards its therapeutic effects [41]. Upon oral administration of curcumin $(1 \mathrm{~g} / \mathrm{kg})$, as a result of first pass metabolism, 
it is rapidly metabolized and $75 \%$ of this valuable agent is eliminated in feces with partial amounts in urine. Up to $50 \%$ of curcumin is excreted in bile following intravenous administration [42]. The major metabolite of curcumin in body is curcumin glucuronide and other metabolites include curcumin sulfate, hydroxycurcumin, hexahydrocurcuminol and hexahydrocurcumin glucuronide. Curcumin is well-tolerated in humans. The concentration of curcumin reaches its peak $1-2 \mathrm{~h}$ after oral administration and begins a decrease after $12 \mathrm{~h} \mathrm{[43].} \mathrm{Oral} \mathrm{administration} \mathrm{of} 8 \mathrm{~g}$ curcumin results in a serum concentration of up to $2 \mu \mathrm{M}$, showing its poor bioavailability. However, curcumin is completely safe in humans, so that its administration for 8 months led to no adverse effect in patients [44].

\section{Antitumor Activity of Curcumin: In Vitro, In Vivo and Clinical Studies}

As a well-known natural product with excellent pharmacological function, antitumor activity of curcumin has been investigated against several sorts of cancer cells in different phases including in vitro, in vivo and clinical studies. Noteworthy, all of the experiments are in agreement with the fact that curcumin is a potential agent in cancer therapy $[30,45]$. Curcumin can impair both proliferation and metastasis of cancer cells via inducing cell cycle arrest, triggering cytoskeletal remodeling and inhibiting epithelial-to-mesenchymal transition (EMT). In this way, molecular pathways such as Wnt and Shh that are involved in cancer progression, undergo downregulation upon curcumin administration [46]. The inhibitory effect of curcumin on viability and colony formation of cancer cells is vital for enhancing sensitivity of cancer cells into chemotherapy [47].

The interesting point is the effect of curcumin on transcription factors in cancer therapy. MicroRNAs (miRNAs) are able to regulate different biological processes in cells and their dysregulation is correlated with the development of cancer $[48,49]$. In suppressing metastasis of cancer cells, curcumin promotes expression of miRNA-34a, as an oncosuppressor to inhibit EMT [50]. In addition to affecting molecular pathways involved in cancer metastasis, curcumin possesses the capacity of targeting molecular pathways that are responsible for cancer growth and survival. Increasing evidence demonstrates association of phosphatidylinositol 3-kinase (PI3K)/protein kinase B (Akt) pathway with cancer growth and migration [51,52]. Curcumin induces apoptosis and cell cycle arrest at the G2/M phase via the downregulating PI3K/Akt signaling pathway [53]. In vivo experiments have also confirmed the efficacy of curcumin in exerting antiproliferative activity in tumor models $[54,55]$.

It has been demonstrated that antitumor activity of curcumin is dose- and time-dependent [56]. Noteworthy, combination of curcumin and chemotherapeutic agents is recommended in clinical studies [57]. Using nanocarriers such as liposomes significantly promote antitumor activity of curcumin in cancer therapy and is well-tolerated [58]. Although we mentioned poor bioavailability of curcumin as a barrier for its therapeutic effects, a clinical study has demonstrated plasma levels of curcumin as much as $22-41 \mathrm{ng} / \mathrm{mL}$ for 4 weeks that is of importance in the treatment of cancer patients [59]. So, studies are in agreement with potential antitumor activity of curcumin against different cancers and capability of targeting molecular pathways [60-62].

\section{Curcumin in Cancer Chemotherapy: Beyond Doxorubicin}

Based on the biological activities of curcumin (e.g., antioxidant and anti-inflammatory, and along with antitumor activity) a large number of experiments have been conducted using curcumin in combination chemotherapy. This section deals with a brief explanation for using curcumin as an adjuvant to enhance antitumor activity and diminishing the side effects of chemotherapeutic agents.

Paclitaxel resistance is frequently observed in cancer therapy and is associated with poor prognosis. Nuclear factor-kappaB (NF- $\mathrm{kB})$ is suggested to be involved in mediating paclitaxel resistance in hepatocellular carcinoma (HCC) via upregulating Lin28B. Curcumin administration $(5,10$ and $20 \mu \mathrm{M})$ leads to suppressing NF- $\mathrm{kB}$-mediated Lin28B and preventing paclitaxel resistance in HCC cells [63]. It is worth mentioning that curcumin is capable of affecting drug transporters in enhancing sensitivity of cancer cells to paclitaxel chemotherapy. In this way, curcumin reduces activity and expression of p-glycoprotein (P-gp) and multidrug resistance-1 (MDR1) to promote paclitaxel 
accumulation in cancer cells [64]. Nanotechnology can provide a platform for codelivery of curcumin and paclitaxel. This results in promoting the bioavailability and enhancing accumulation in the cargo in cancer cells $[65,66]$. This consequence is of importance in providing effective cancer chemotherapy. Curcumin is beneficial in the alleviation of side effects of cisplatin during chemotherapy. For instance, curcumin $(200 \mathrm{mg} / \mathrm{kg}$ ) can improve renal fibrosis during cisplatin chemotherapy downregulation of transforming growth factor-beta 1 (TGF- $\beta 1$ ) [67].

Nuclear factor erythroid 2-related factor 2 (Nrf2) as a molecular pathway involved in reinforcing the antioxidant defense system [68] is upregulated by curcumin in reducing cisplatin-mediated nephrotoxicity [69]. In suppressing cisplatin resistance, curcumin upregulates expression of miRNA-497 to sensitize cancer cells to apoptosis [70]. Overall, studies show that curcumin is a potential agent for ameliorating side effects of chemotherapeutic agents and enhancing their cytotoxicity against cancer cells [71-73]. In the following section, we evaluated the potential application of curcumin in reversing doxorubicin resistance and reducing its adverse effects.

\section{Doxorubicin: Cancer Resistance and Side Effects}

Doxorubicin (DOX) is a member of anthracycline antibiotic family derived from fungus Streptomyces peucetius var. caesius [74]. DOX has four anthraquinone rings with connection to one amino sugar moiety [75]. The first discovery towards antitumor activity of DOX returns back to 1950, but its application in the clinic was approved in 1963. The preferred administration route for DOX is intravenous with a recommendation dose of $50-75 \mathrm{mg} \cdot \mathrm{m}^{2}$. DOX is administered in a single dose and repetition occurs after 21 days [75-77]. DOX interferes with cancer progression via intercalation with DNA and reducing activity of topoisomerase II, resulting in suppressing DNA replication. Although DOX demonstrated potential antitumor activity against different cancer cells, it was soon found that its efficiency in cancer therapy is restricted by a phenomenon known as chemoresistance.

To date, a high number of molecular pathways and mechanisms have been identified that contribute to DOX resistance. Trefoil factor 3 (TFF3) is a secreted protein with overexpression in small and large intestines and is correlated with enhanced cell migration [78]. Antiapoptotic and proproliferative functions of TFF3 are mediated by its trefoil domain and a cysteine residue (Cys057) in carboxy-terminal $[79,80]$. Following doxorubicin administration, an increase occurs in the expression of TFF3 and Akt that are responsible for cancer proliferation and inhibiting apoptosis. It has been reported that downregulation of TFF3 provides the way for enhancing apoptosis and doxorubicin sensitivity [81].

Uncontrolled proliferation of cancer cells is dependent on glucose uptake and glycolysis. Sphingosine kinase 1 (SphK1) accounts for triggering cancer chemoresistance and also, elevating glycolysis [82-84]. A newly published article has shed some light on the relationship between SphK1 and DOX resistance in osteosarcoma (OS) cells. Exposing OS cells to DOX is associated with upregulation of SphK1 and subsequent increase in glucose metabolism, leading to induction of chemoresistance [85].

Noteworthy, non-coding RNAs also play a significant role in DOX resistance. It seems that enhancing expression of oncosuppressor miRNAs such as miRNA-124 [86] and miRNA-223 [87] is of importance in impairing cancer proliferation and migration, and increasing their sensitivity into DOX chemotherapy. Furthermore, reducing activity of drug transporters such as P-gp elevates DOX accumulation in cancer cells and is of importance in reversing chemoresistance [88]. Overall, studies are in agreement with the fact that different molecular pathways and mechanisms can involve in inducing DOX chemoresistance and phytochemical are potential agents in triggering chemosensitivity [89-92].

However, chemoresistance is not the only drawback of DOX. A dose-dependent side effect is another challenge in DOX chemotherapy. Cardiotoxicity, hepatotoxicity and nephrotoxicity of major adverse effects of DOX. Stimulation of molecular pathways such as Akt that promote cell proliferation is of importance in reducing DOX side effects [93]. Non-coding RNAs such as miRNA-146a are able to prevent apoptotic cell death in improving DOX-mediated cardiotoxicity [94]. 
Noteworthy, plant derived-natural products have been extensively applied in improving DOX side effects. These agents enhance activity of antioxidant enzymes such as superoxide dismutase (SOD) and glutathione (GSH), while they diminish malondialdehyde (MDH) levels in preventing cardiotoxicity [95], through upregulation of Nrf2 signaling pathway [96].

In alleviation of DOX toxicity, phytochemicals reduce levels of proinflammatory cytokines via downregulating NF- $\mathrm{kB}$ signaling pathway [97]. Furthermore, apoptotic proteins such as Bax and caspase-3 undergo downregulation, while antiapoptotic factor Bcl-2 demonstrates an increase in expression to ameliorate DOX side effects [98]. Taking everything into together, studies demonstrate that inflammation, oxidative stress and apoptosis are induced following DOX exposure in normal cells and protective agents possess regulatory effect on aforementioned mechanisms in reducing adverse effects of DOX [99-102]. Figure 1 demonstrates the chemical structure of curcumin and doxorubicin.

a

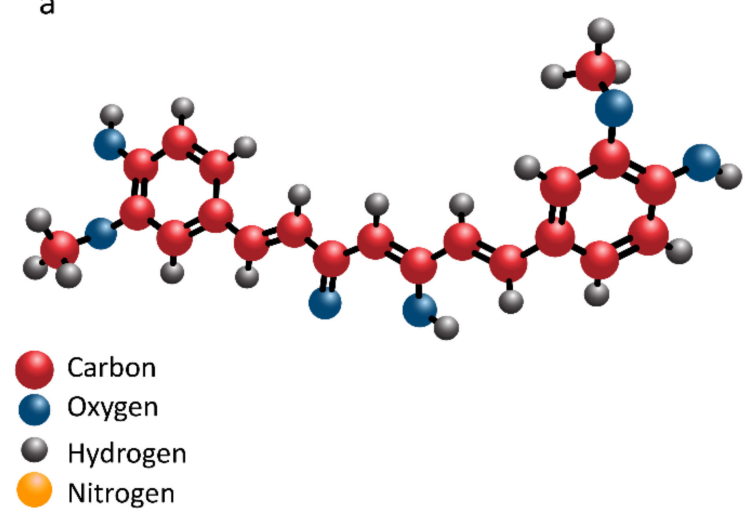

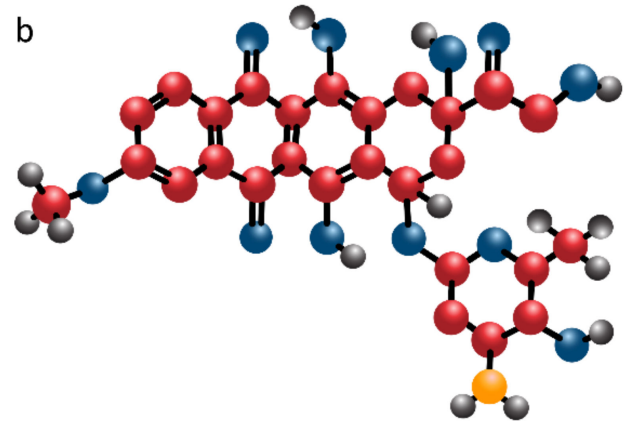

b

Figure 1. The chemical structure of curcumin (a) and doxorubicin (b).

\section{Curcumin in Combination with Doxorubicin}

\subsection{Anticancer Effects}

\subsubsection{Apoptosis Induction}

Neuroblastoma is one of the common solid extracranial cancers in children that forms in tissues of the sympathetic nervous system [103]. Neuroblastoma is responsible for up to $15 \%$ of death in children [104]. The most important issue in neuroblastoma is the metastasis of these malignant cells. Up to $70 \%$ of neuroblastoma cells possesses metastatic capability and are able to involve bone, bone marrow and liver during migration $[105,106]$. Furthermore, they demonstrate uncontrolled growth. So, having a potential regimen for suppressing malignant behavior of neuroblastoma is recommended.

Coadministration of curcumin $(5-50 \mu \mathrm{M})$ with DOX results in a decrease in viability and proliferation of neuroblastoma cells by apoptosis induction via upregulating p53 and p21. These effects are dose-dependent (with highest inhibitory effect at dose of $50 \mu \mathrm{M}$ ) [107]. Another highlights the fact that time is also important, so that a combination of curcumin $(0-30 \mu \mathrm{g} / \mathrm{mL})$ and DOX substantially induces apoptosis via Bcl-2 downregulation, and Bax, and caspase-9 upregulation in a time- and dose-dependent manner [108]. In induction of apoptosis during DOX chemotherapy, curcumin is able to affect other proapoptotic factors plus p53 and p21. Curcumin $(100 \mathrm{mg} / \mathrm{kg})$ promotes expression of caspase-3, -8 and -9 in potentiating antitumor activity of DOX [109].

The composition of gut microbiota determines the response to chemotherapeutic agents and checkpoint inhibitor therapies [110]. Gut microbiota is a key player in preserving mucosal barrier integrity and micronutrient levels such as $\mathrm{Zn}$ homeostasis. It has been reported that changes in $\mathrm{Zn}$ levels is correlated with emergence of HCC and a low potential of chemotherapy. Furthermore, clinical studies have revealed that patients with low levels of $\mathrm{Zn}$ demonstrate an increase in tumor 
size [111,112]. In order to meet these difficulties, curcumin-Zn solid dispersion (ZnCM-SD) has been developed for promoting efficacy of DOX in HCC therapy. ZnCM-SD is taken up by cells through non-specific endocytosis and is degraded in cells to $\mathrm{Zn}$ ions and curcumin. This combination synergistically suppresses cancer growth and viability and induces apoptosis in HCC cells. This is performed by preventing gut dysbiosis and regulating zinc homeostasis. This inhibitory effect of ZnCM-SD on HCC survival leads to enhanced efficacy of DOX in cancer chemotherapy [113].

\subsubsection{Metastasis Inhibition}

Matrix metalloproteinase-2 is a determinant factor of cell migration. It enhances invasion of cancer cells via providing extracellular matrix (ECM) and basement membranes degradation [114,115]. Tissue inhibitors of metalloproteinases (TIMPs) are endogenous inhibitors of MMPs. TIMP-1 reduces expression of MMP-2 in impairing cancer migration [116,117]. Curcumin reduces migration of neuroblastoma cells and enhances their sensitivity to DOX chemotherapy by enhancing TIMP-1 expression and reducing MMP-2 expression [107].

Epithelial-to-mesenchymal transition (EMT) is a process in which epithelial cells acquire the mesenchymal phenotype [118]. Mesenchymal phenotypes possess stem cell features, increased generation of ECM components and enhanced cell migration [119-122]. Different molecular pathways act as upstream mediators of EMT in cancer progression. TGF- $\beta$ signaling pathway is an EMT inducer in cancer cells and in this way, can provide chemoresistance [123,124]. PI3K/Akt signaling can also induce EMT in cancer cells, and its downregulation is associated with a decrease in EMT $[125,126]$. Noteworthy, curcumin has demonstrated capacity of affecting both aforementioned signaling networks in impairing EMT. Curcumin $(20 \mu \mathrm{M})$ substantially promotes antitumor activity of DOX against triple-negative breast cancer cells by suppressing EMT and metastasis. In this way, curcumin downregulates expression of TGF- $\beta$ and PI3K/Akt that are vital for EMT induction. Consequently, an increase occurs in E-cadherin levels, while N-cadherin levels demonstrate a decrease, paving the way for inhibiting EMT and enhancing antitumor activity of DOX [127].

Taking everything into account, studies are in agreement with the fact that curcumin is a potential adjuvant for polychemotherapy with DOX. It induces apoptosis in cancer cells via affecting caspase cascade and pro- and antiapoptotic proteins. Migration of cancer cells is disrupted by curcumin. Besides, gut dysbiosis is improved by curcumin in promoting efficacy of DOX in chemotherapy.

\subsection{Effects on Resistance}

\subsubsection{Potential Mechanisms of DOX Resistance}

ATP-binding cassette $(\mathrm{ABC})$ transporters are one of the most important factors involved in triggering chemoresistance. In addition to chemoresistance, $\mathrm{ABC}$ transporters contribute to material transportation and cellular homeostasis [128]. Most of the ABC transporters in eukaryotes are efflux transporters that provide elimination of chemotherapeutic agents from cells at the route of cytoplasm to extracellular space [128]. ABC sub-family B member 4 (ABCB4) has high sequence similarity with ABCB1 (up to $80 \%$ ) and participates in chemoresistance [129]. PI3K acts as an upstream mediator of P-gp in cancer cells, and reducing its expression is correlated with downregulation of P-gp and chemosensitivity [130]. Notably, phytochemicals are potential agents in suppressing P-gp expression and promoting DOX sensitivity [131]. The interesting point is that activity of P-gp can be affected by other proteins in cancer cells. S100 calcium-binding protein A8 (S100A8) belongs to S100 multigene subfamilies and is correlated with cancer progression [132,133]. Accumulating data demonstrates role of S100A8 in chemoresistance [134].

\subsubsection{Curcumin in Reversing DOX Resistance}

Curcumin administration $(0-100 \mu \mathrm{M})$ enhances internalization and accumulation of DOX in breast cancer cells to improve its antitumor activity and suppress chemoresistance. It has been reported that 
this activity is mediated via reducing activity and expression of $\mathrm{ABCB} 4$, as a potential factor involved in pumping DOX out of breast cancer cells [135]. Inhibiting activity of P-gp is associated with mitotic slippage and apoptosis induction in multidrug resistance lung cancer cells [136]. In order to improve efficacy of curcumin in inhibiting P-gp activity upon DOX treatment, a combination of tannic acid and epigallocatechin gallate (EGCG) was used with curcumin. Results confirmed that leukemia cells are sensitive towards inhibitory effects of DOX after using a mixture of curcumin, EGCG and tannic acid. This is attributed to downregulation of P-gp that is of importance for enhancing intracellular accumulation of DOX in cancer cells [137].

In DOX-resistant leukemia cells, an increase occurs in expression of P-gp and S100A8. Downregulation of S100A8 enhances sensitivity of cancer cells to DOX chemotherapy. The increased sensitivity of cancer cells to DOX chemotherapy upon S100A8 inhibition is not due to enhanced accumulation of DOX, but also due to enhanced intracellular free calcium ion content and overexpression of proapoptotic proteins. Curcumin $(0-32 \mu \mathrm{M})$ as a potential antitumor agent, reduces expression of S100A8 and P-gp in a time- and dose-dependent manner to promote DOX accumulation and induce apoptosis in leukemia cells [138]. These studies demonstrate that drug transporters participate in DOX resistance and they are potential targets of curcumin in providing chemosensitivity. As an example, it was shown that colocal delivery of DOX and curcumin can synergistically increase the effectiveness toward multidrug-resistant cancer cells, e.g., further reducing the $I C_{50}$ value by $37 \%$ $(8.9 \mu \mathrm{g} / \mathrm{mL}$; Figure 2) [139].

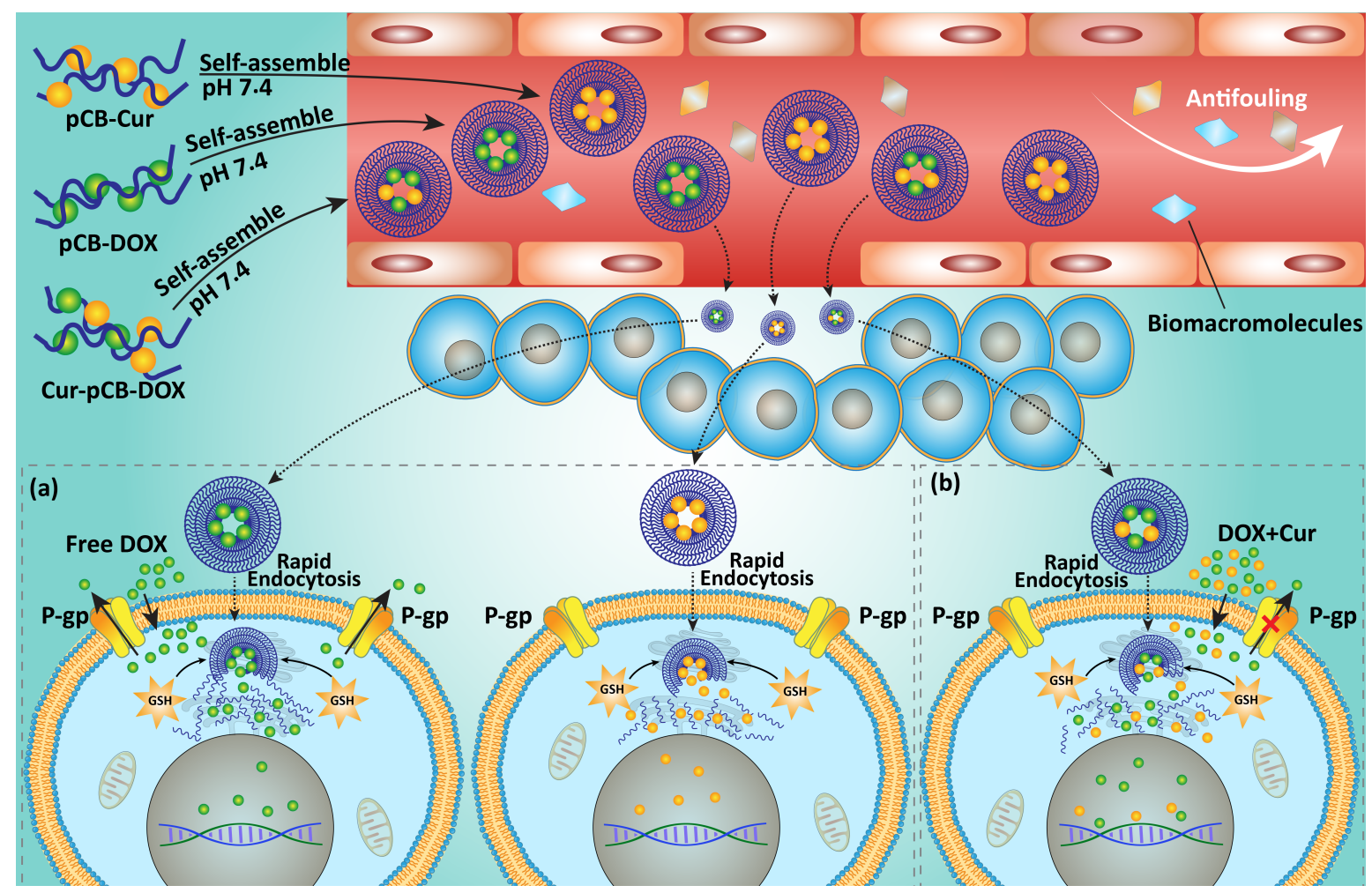

Figure 2. Schematic diagram of the proposed mechanism for promoting cellular uptake and overcoming MDR by Cur-pCB (poly(carboxybetaine)) -Dox in MCF-7/Adr cells. The nanosized feature of the zwitterionic antifouling micelles and endocytic pathway to bypass P-gp-mediated drug efflux led to high cellular uptake of the conjugated drugs that were released in the tumor cells of high GSH concentration. 
However, pCB-Dox and pCB-Cur can be delivered separately into different cells so that the drugs fail to play a synergistic role in inhibiting the MDR effect (a). By contrast, Cur-pCB-Dox codelivers Dox and Cur into the same tumor cells and results in synergistic effects of the two drugs (b). Merging images of cell uptake of pCB-Dox (left), pCB-Dox + pCB-Cur (middle) and Cur-pCB-Dox (right) in MFC-7/Adr cells (c). Cur: curcumin; Dox: doxorubicin; MDR: multidrug resistance; pCB: poly(carboxybetaine). Addapted with permission from [139].

Increasing evidence demonstrates the role of NF- $\mathrm{BB}$ and activator protein-1 (AP-1) in triggering chemoresistance $[140,141]$. These two molecular pathways are potential targets of curcumin in reversing chemoresistance. It is held that curcumin $(0-50 \mu \mathrm{mol} / \mathrm{L})$ reduces expression of AP-1 and NF- $\mathrm{kB}$ via downregulation of Akt and JNK. Negative regulation of these signaling networks is vital for induction of apoptosis by curcumin in glioblastoma cells and providing chemosensitivity. In enhancing sensitivity to doxorubicin chemotherapy, curcumin also reduces expression of DNA repair enzymes such as MGMT, DNA-PK, ERCC-1, Ku70 and Ku80 to potentiate DNA damage [142].

Noteworthy, curcumin derivatives have also demonstrated great capability in reversing DOX resistance. HER2 is suggested to be involved in chemoresistance [143]. The exact mechanism in which HER2 induces chemoresistance has not been understood. A recent study has shown that downregulation of miRNA-196a-5p occurs during chemoresistance that provides HER2 overexpression [144]. Curcumin and its derivatives (PGV-0 and PGV-1) downregulate expression of NF- $\mathrm{kB}$ and HER2 to induce cell cycle arrest at the G1 phase, leading to enhanced sensitivity of breast cancer cells to DOX chemotherapy [145].

Using nanoparticles such as micelles remarkably promotes intracellular uptake of curcumin and DOX, leading to more efficiency in suppressing chemoresistance compared to DOX or curcumin alone [139]. The ideology of coadministration of curcumin and DOX during cancer chemotherapy was better advocated, when it was found that DOX is also capable of promoting cellular uptake of curcumin in enhancing its antitumor activity against prostate cancer cells [146]. This study demonstrates dual relationship between curcumin and DOX in cancer cells, urging scientists for their coadministration in providing effective cancer chemotherapy (Figure 3, Table 1) [147].

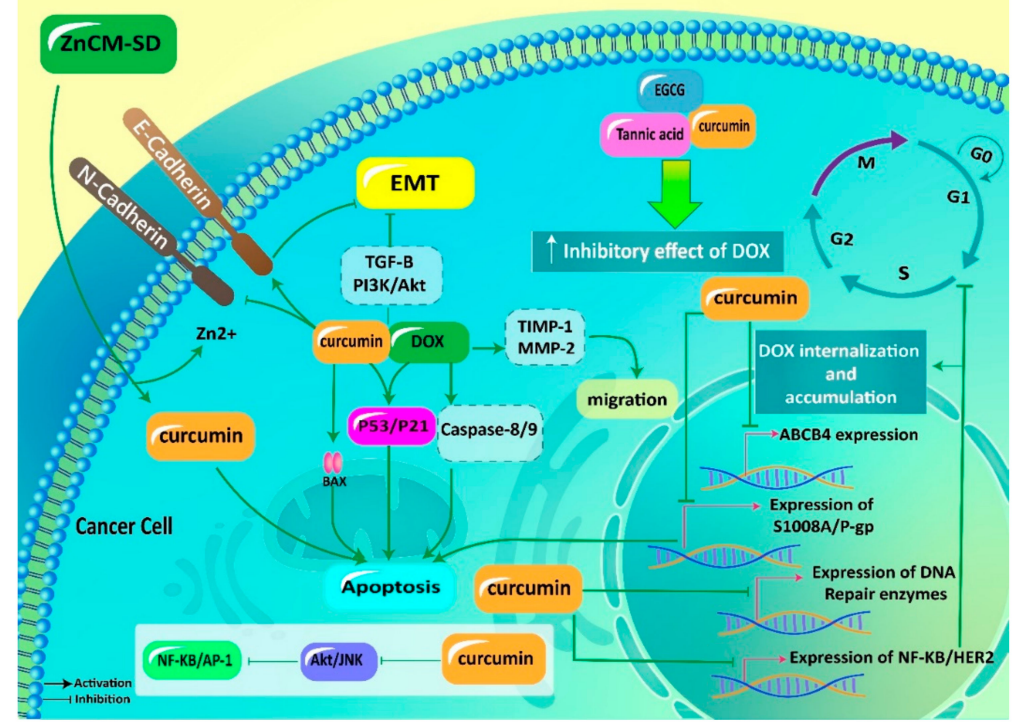

Figure 3. Curcumin in promoting antitumor activity of DOX and reversing chemoresistance. ZnCM-SD, curcumin-Zn solid dispersion; EMT, epithelial-to-mesenchymal transition; TGF- $\beta$, transforming growth factor-beta; PI3K, phosphatidylinositol 3-kinase; Akt, protein kinase B; DOX, doxorubicin; TIMP-1, tissue inhibitor of matrix metalloproteinase-1; MMP-2, matrix metalloproteinase-2; EGCG, epigallocatechin gallate; AP-1, activator protein-1; NF-kB, nuclear factor-kappaB; P-gp, P-glycoprotein. 
Table 1. Curcumin as an enhancer of antitumor activity upon doxorubicin chemotherapy.

\begin{tabular}{|c|c|c|c|c|c|c|c|}
\hline Cancer Type & In Vitro/In Vivo & $\begin{array}{l}\text { Cell Line/Animal } \\
\text { Model }\end{array}$ & $\begin{array}{c}\text { Effect on } \\
\text { Doxorubicin } \\
\text { Efficacy }\end{array}$ & Dose & $\begin{array}{l}\text { Experiment } \\
\text { Duration }\end{array}$ & Remarks & Refs \\
\hline Glioblastoma & In Vitro & $\begin{array}{l}\text { T98G (world health } \\
\text { organization (WHO) } \\
\text { grade IV), U87MG } \\
\text { (WHO grade III), and } \\
\text { T67 (WHO grade III) } \\
\text { human glioma and C6 } \\
\text { rat glioma cell lines } \\
\end{array}$ & Enhancement & $\begin{array}{l}20,40 \text { and } \\
60 \mu \mathrm{mol} / \mathrm{L}\end{array}$ & $48 \mathrm{~h}$ & $\begin{array}{c}\text { Promoting inhibitory effect of DOX on } \\
\text { cancer cells } \\
\text { Reversing chemoresistance } \\
\text { Downregulation of AP-1 and NF- } \mathrm{kB} \\
\text { Apoptosis induction } \\
\text { Inhibiting JNK and Akt signaling } \\
\text { pathways } \\
\end{array}$ & [142] \\
\hline Breast cancer & In Vitro & MCF-7 cells & Enhancement & $6-110 \mu \mathrm{M}$ & $24 \mathrm{~h}$ & $\begin{array}{c}\text { Downregulation of HER2 and NF- } \mathrm{kB} \\
\text { Subsequent sensitivity into DOX } \\
\text { chemotherapy }\end{array}$ & [145] \\
\hline Breast cancer & In Vitro & $\begin{array}{c}\text { MCF-7 and } \\
\text { MDA-MB-231 cells }\end{array}$ & Enhancement & $0-100 \mu \mathrm{M}$ & $72 \mathrm{~h}$ & $\begin{array}{l}\text { Downregulation of ABCB4 } \\
\text { Increasing DOX accumulation and } \\
\text { cytotoxicity }\end{array}$ & [135] \\
\hline $\begin{array}{c}\text { Chronic myeloid } \\
\text { leukemia }\end{array}$ & In Vitro & $\begin{array}{l}\text { Human CML cell lines } \\
\text { K562 and K562/DOX }\end{array}$ & Enhancement & $0.5,1$ and $2 \mu \mathrm{M}$ & $48 \mathrm{~h}$ & $\begin{array}{c}\text { Promoting sensitivity into DOX } \\
\text { chemotherapy via P-gp and S100A8 } \\
\text { downregulation }\end{array}$ & [138] \\
\hline Hepatic cancer & In Vitro & HA22T/VGH cells & Enhancement & $\begin{array}{c}10,15,20 \text { and } \\
25 \mu \mathrm{M}\end{array}$ & $72 \mathrm{~h}$ & $\begin{array}{l}\text { Downregulation of c-Myc and COX-2 } \\
\text { Decreasing expression of Bcl-2, Bcl-Xl } \\
\text { and c-IAP-2 levels } \\
\text { Apoptosis induction }\end{array}$ & [147] \\
\hline $\begin{array}{l}\text { Colon cancer } \\
\text { Breast cancer }\end{array}$ & In Vitro & $\begin{array}{l}\text { Human colon HCT116 } \\
\text { and breast cancer } \\
\text { MCF7 cell lines }\end{array}$ & Enhancement & $15 \mu \mathrm{M}$ & - & $\begin{array}{c}\text { Apoptosis induction } \\
\text { Exerting antiproliferative activity } \\
\text { Enhancing DOX efficacy }\end{array}$ & [148] \\
\hline Neuroblastoma & In vitro & SH-SY5Y cells & Enhancement & $5-50 \mu \mathrm{M}$ & $24 \mathrm{~h}$ & $\begin{array}{l}\text { Disrupting cancer invasion } \\
\text { Downregulation of MMP-2 } \\
\text { Upregulation of TIMP-1 } \\
\text { Enhancing DOX sensitivity }\end{array}$ & [107] \\
\hline $\begin{array}{c}\text { Gastric } \\
\text { adenocarcinoma }\end{array}$ & In Vitro & AGS cells & Enhancement & $0-30 \mu \mathrm{g} / \mathrm{mL}$ & $24,48,72$ and $96 \mathrm{~h}$ & $\begin{array}{l}\text { Apoptosis stimulation via Bcl-2 } \\
\text { downregulation and Bax and caspase- } 9 \\
\quad \text { upregulation } \\
\text { Suppressing tumor spheroid formation, } \\
\text { proliferation and metastasis }\end{array}$ & [108] \\
\hline
\end{tabular}


These studies highlight the fact that P-gp and ABCB4 are able to induce DOX resistance by preventing DOX accumulation in cancer cells. Impairing activity and expression of P-gp and ABCB4 by curcumin results in enhanced internalization of DOX in cancer cells and providing chemosensitivity. Notably, signaling pathways that promote cancer progression including NF- $\mathrm{kB}, \mathrm{AP}-1$ and PI3K/Akt, are inhibited by curcumin to suppress cancer proliferation, resulting in an increase in DOX sensitivity.

\subsection{Impact on Adverse Effects}

The clinical application of DOX is limited due to its dose-dependent cardiotoxicity. Oxidative stress, iron-loading disorders, calcium dysregulation, inflammation and apoptosis contribute to DOX-mediated cardiomyopathy [149]. Noteworthy, gut microbiota plays a significant role in the regulation of chemotherapy-mediated toxicity [150-152]. Gut dysbiosis is a common finding in cancer [153]. Studies have shown the importance of gut microbiota in DOX toxicity. It seems that gut microbiota depletion leads to a decrease in DOX-mediated toxicity in heart, kidney, liver and intestine [154,155]. Following DOX exposure, gut dysbiosis occurs that may lead to disruption in the intestinal barrier. An impairment occurs in heart function and cardiomyocytes undergo apoptosis. A combination of curcumin and $\mathrm{Zn}$ improves DOX-mediated gut dysbiosis via enhancing the number of beneficial bacteria including Clostridium_XIVa, Clostridium_IV, Roseburia, Butyricicoccus and Akkermansia. This combination also maintains intestine barrier integrity and prevents DOX-mediated zinc dyshomeostasis. Apoptosis in cardiomyocytes is inhibited and an improvement occurs in heart function [156].

The pathogenesis of DOX-mediated cardiotoxicity has been completely understood. However, studies demonstrate the potential role of inflammation, oxidative stress and apoptosis in triggering cardiotoxicity following DOX chemotherapy [157]. Curcumin administration (100 and $200 \mathrm{mg} / \mathrm{kg}$ ) enhances activities of antioxidant enzymes such as SOD, GSH and catalase (CAT) in reducing oxidative stress. Besides, curcumin inhibits inflammation via downregulation of NF- $\mathrm{kB}$, tumor necrosis factor-alpha (TNF- $\alpha$ ) and interleukin-1 $\beta$ (IL-1 $\beta$ ). A decrease occurs in apoptosis following curcumin administration by caspase-3 downregulation. Furthermore, DNA damage is prevented. These protective effects lead to an alleviation in DOX-mediated cardiotoxicity [158].

It is worth mentioning that curcumin can be coadministered with other naturally occurring compounds in improving its capacity in ameliorating DOX-mediated cardiotoxicity. Carvacrol (CAR) is a phenol compound present in essential oils of plant species such as Origanum, Thymus and Coridothymus. $\mathrm{CAR}$ has demonstrated potential cardioprotective effects. For instance, it can ameliorate diabetic cardiomyopathy via triggering PI3K/Akt pathway via PTEN downregulation [159]. Furthermore, it is beneficial in improving pathologic cardiac hypertrophy [160]. A combination of curcumin $(100 \mathrm{mg} / \mathrm{kg})$ and CAR $(50 \mathrm{mg} / \mathrm{kg})$ is advantageous in protecting cardiomyocytes against DOX toxicity. This combination heals the heart function and reduces the volume of connective tissues and cardiomyocytes. Furthermore, curcumin and CAR promote the volume of myocardium and vessels, and number of cardiomyocyte nuclei in preventing DOX-mediated toxicity [161].

Mitochondrial phosphate carrier $(\mathrm{PiC})$ contributes to importing phosphate across inner membrane of mitochondria [162]. The role of $\mathrm{PiC}$ in releasing cytochrome $\mathrm{C}$ from mitochondria, activating caspase cascade and apoptosis induction has been confirmed [163]. Increased levels of PiC are associated with cell death, but decreasing its levels is correlated with a decrease in apoptosis [162]. Curcumin uses a same strategy in protecting against DOX-mediated cardiotoxicity. Curcumin (10, 12 and $15 \mathrm{mg} / \mathrm{L})$ prevents cardiomyocyte apoptosis following DOX chemotherapy. In this way, curcumin reduces mRNA levels of $\mathrm{PiC}$, as a major pathway for inhibiting apoptosis. Furthermore, curcumin diminishes oxidative stress to prevent mitochondrial dysfunction and subsequent apoptosis in cardiomyocytes [164]. It seems that maintaining mitochondrial function via reducing ROS levels is the major way that is followed by curcumin in preventing DOX-mediated cardiotoxicity [165].

Notably, cardioprotective activity of curcumin against DOX toxicity can be improved using nanoparticles. Mesoporous silica nanoparticles (MSNs) significantly promote bioavailability of 
curcumin that is beneficial for decreasing oxidative damage and reinforcing the antioxidant defense system by enhancing activities of SOD, CAT and GSH [166]. According to the fact that poor bioavailability of curcumin is a barrier for its therapeutic effects, loading curcumin on nanoparticles remarkably promotes its bioavailability that is of importance for preventing DOX-mediated cardiotoxicity [167]. It is held that enhancing ROS overgeneration by DOX leads to the stimulation of mitochondrial pathway of apoptosis. Due to possessing high antioxidant activity, curcumin reduces levels of ROS in preventing DOX-mediated cardiotoxicity.

It was mentioned that curcumin exerts its cardioprotective effect in a dose- and time-dependent manner. Mode of treatment is also a determining factor in protective effects of curcumin. Simultaneous treatment of cardiomyocytes with curcumin and DOX potentiates cardiotoxicity of DOX, while pretreatment with curcumin is of importance in repressing DOX-mediated cardiotoxicity [168]. So, time, dose and mode of treatment are important for cardioprotective activity of curcumin and using nanoparticles significantly promotes therapeutic efficacy of curcumin [167].

Previously, we demonstrated that heart is the main target of DOX. Heart function is disrupted after DOX chemotherapy, and apoptosis occurs in cardiomyocytes. However, heart is not the only target of DOX. It has been shown that testis is negatively affected by DOX during chemotherapy. The same pathways are followed for providing DOX toxicity on testis including inflammation, oxidative stress and apoptosis. Curcumin administration (100 and $200 \mathrm{mg} / \mathrm{kg}$ ) for 7 days significantly promotes sperm motility and the number of live sperms. It decreases $\mathrm{MDH}$ levels and improves the antioxidant condition. Necrosis, degeneration, slimming in seminiferous tubules and DNA damage are prevented following curcumin administration. These protective effects of curcumin against DOX-mediated testis toxicity are dose-dependent with the highest protective effect at dose of $200 \mathrm{mg} / \mathrm{kg}$ [169].

Kidney is also negatively affected by DOX in chemotherapy. Tubular atrophy and enhanced glomerular capillary permeability occurs following DOX chemotherapy [170]. ROS are considered as the main factors in this process [171]. Curcumin administration (100 and $200 \mathrm{mg} / \mathrm{kg}$ ) for 7 days decreases oxidative damage in kidney via promoting activity of antioxidant enzymes such as SOD, CAT and GSH. Inflammation is inhibited by curcumin via downregulation of TNF- $\alpha, N F-\kappa B$, IL- $1 \beta$, COX-2 and iNOS. Furthermore, curcumin prevents DNA damage and suppresses apoptosis through reducing expressions of capase-3 [172]. Nephrotic syndrome (NS) emanates from severe proteinuria due to edema and intravascular volume depletion [173]. A recent study has revealed that DOX is able to induce NS in rats. Consequently, curcumin has been applied for alleviation of this pathological condition. It seems that curcumin $(100$ and $200 \mathrm{mg} / \mathrm{kg})$ is a promising candidate in amelioration of DOX-mediated NS. Curcumin attenuates proteinuria and is beneficial in improving hypoalbuminemia. Curcumin also reduces lipid levels to ameliorate hyperlipidemia in rats [174]. As it was mentioned before, inflammation and oxidative stress are two major pathways for providing DOX-mediated nephrotoxicity. NF-kB participated in inflammation [175] and curcumin downregulates its expression in improving NS [174].

Oxidative stress is ameliorated by upregulation of Nrf2 signaling pathway, as a factor involved in enhancing expression of antioxidant enzymes such as heme oxygenase-1 (HO-1) and NAD(P)H dehydrogenase [quinone] 1 (NQO1) [176,177]. By upregulation of Nrf2, curcumin reinforces the antioxidant defense system, resulting in alleviation of NS [174]. Conducted experiments related to protective effects of curcumin against DOX-mediated cardiotoxicity demonstrate that inflammation, oxidative stress and apoptosis are the major mechanisms responsible for cardiotoxicity of DOX. Due to possessing antioxidant and anti-inflammatory activities, curcumin can effectively alleviate DOX-mediated cardiotoxicity. Further studies can focus on evaluating protective effects of curcumin on other side effects of DOX such as hepatotoxicity, nephrotoxicity and neurotoxicity (Figure 4, Table 2). 
Table 2. Alleviation of adverse effects of doxorubicin by curcumin.

\begin{tabular}{|c|c|c|c|c|c|c|}
\hline In Vitro/In Vivo & Cell Line/Animal Model & Dose & $\begin{array}{c}\text { Experiment } \\
\text { Duration }\end{array}$ & $\begin{array}{c}\text { Administration } \\
\text { Route }\end{array}$ & Remarks & Refs \\
\hline In Vivo & Wistar rats & 100 and $200 \mathrm{mg} / \mathrm{kg}$ & 7 days & Oral gavage & $\begin{array}{l}\text { Reducing oxidative stress } \\
\text { and MDH levels } \\
\text { Promoting sperm motility } \\
\text { and viability } \\
\text { Preventing necrosis and } \\
\text { degeneration }\end{array}$ & [169] \\
\hline In Vivo & Rat & 100 and $200 \mathrm{mg} / \mathrm{kg}$ & 7 days & Oral administration & $\begin{array}{c}\text { Preventing apoptosis via } \\
\text { caspase-3 downregulation } \\
\text { Ameliorating inflammation } \\
\text { via TNF- } \alpha \text { and NF-KB } \\
\text { downregulation } \\
\text { Inhibiting DNA damage }\end{array}$ & [172] \\
\hline In Vivo & $\begin{array}{l}\text { DOX-mediated cardiotoxicity } \\
\text { in rat }\end{array}$ & $\begin{array}{c}100 \mathrm{mg} / \mathrm{kg} \text { of } \\
\text { curcumin } \\
50 \mathrm{mg} / \mathrm{kg} \mathrm{CAR}\end{array}$ & 22 days & $\begin{array}{l}\text { Intraperitoneal } \\
\text { administration }\end{array}$ & $\begin{array}{l}\text { Reducing volume of } \\
\text { myocardium and vessels } \\
\text { Decreasing number of } \\
\text { cardiomyocyte nuclei } \\
\text { Improving heart function } \\
\text { Decreasing connective tissue } \\
\text { volume }\end{array}$ & [161] \\
\hline In Vivo & Rat & 100 and $200 \mathrm{mg} / \mathrm{kg}$ & 7 days & Oral administration & $\begin{array}{c}\text { Alleviation of oxidative } \\
\text { stress, inflammation, } \\
\text { apoptosis and DNA damage } \\
\text { Downregulation of TNF- } \alpha \\
\text { and NF-kB }\end{array}$ & [158] \\
\hline In Vivo & Rat & $\begin{array}{c}100 \text { and } 200 \mathrm{mg} / \mathrm{kg} \text { of } \\
\text { curcumin } \\
1 \text { and } 2 \mathrm{mg} / \mathrm{kg} \text { of } \\
\text { nebivolol }\end{array}$ & 30 days & $\begin{array}{l}\text { Intraperitoneal } \\
\text { administration }\end{array}$ & $\begin{array}{c}\text { Enhancing survival rate } \\
\text { Improving body weight, } \\
\text { heart index and ECG } \\
\text { parameters } \\
\text { Preventing oxidative damage } \\
\text { and apoptosis }\end{array}$ & [178] \\
\hline
\end{tabular}




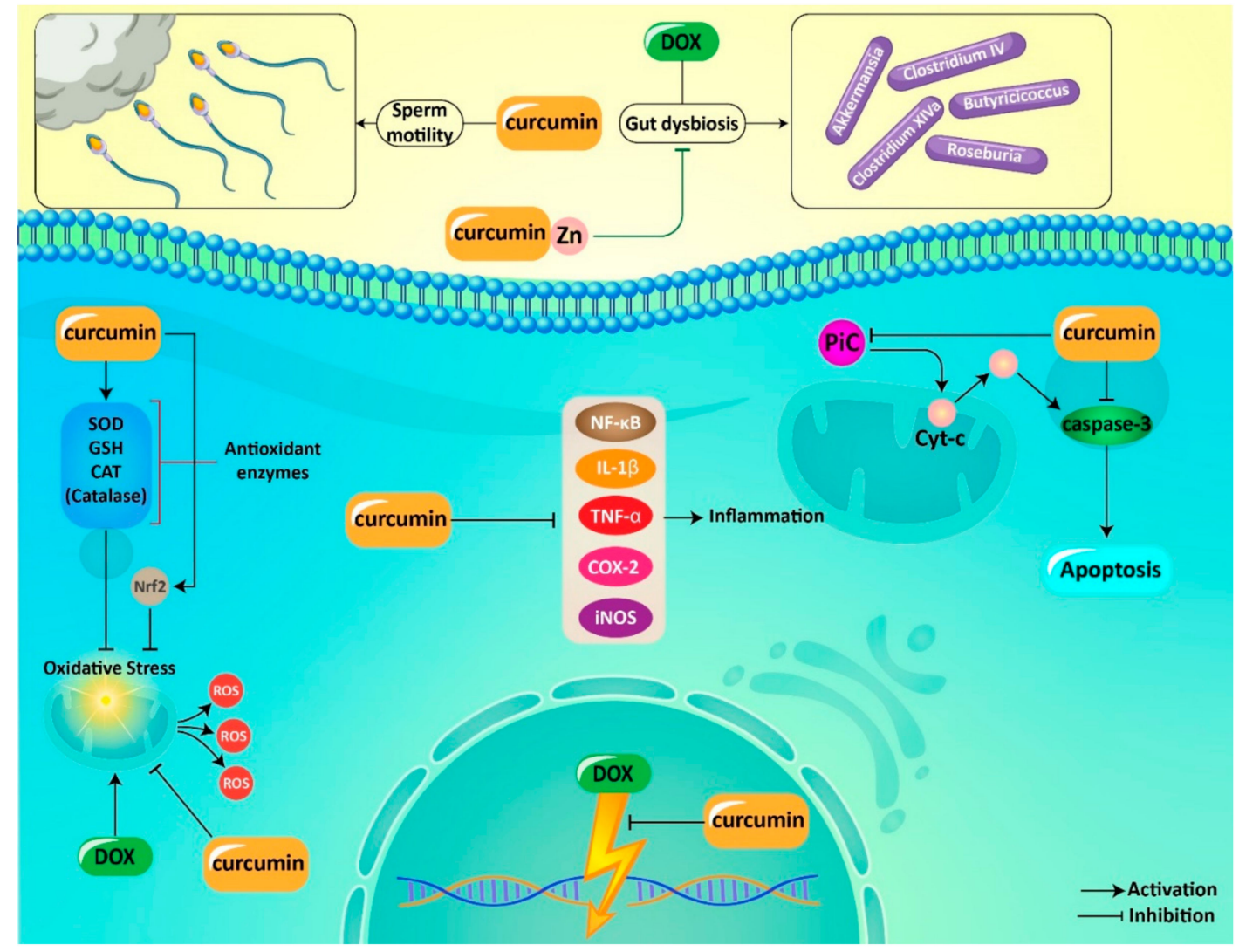

Figure 4. Curcumin in alleviation of adverse effects of DOX during chemotherapy. DOX, doxorubicin; cyt c, cytochrome C; NF- $\mathrm{B}$, nuclear factor-kappa B; IL-1 $\beta$, interleukin- $1 \beta$; TNF- $\alpha$, tumor necrosis factor-a; COX-2, cyclooxygenase-2; iNOS, inducible nitric oxide synthase; SOD, superoxide dismutase; GSH, glutathione; CAT, catalase; ROS, reactive oxygen species; PiC, mitochondrial phosphate carrier.

\section{Codelivery via Biological Nanovehicles}

It is worth mentioning that both DOX and curcumin suffer from poor bioavailability. In light of this, a wide variety of nanoplatforms have been developed for codelivery of curcumin and DOX [179-181]. In addition to promoting cellular internalization of DOX, nanocarriers can prevent development of chemoresistance, since a low amount of DOX is loaded on/in the encapsulants. Thus, it is quite obvious that using nanostructures is beneficial for polychemotherapy of curcumin and DOX. This section highlights the application of various nanosized carriers for codelivery of curcumin and DOX in cancer therapy.

Previous studies have confirmed the potential of lipid nanoparticles for delivery of curcumin [182,183] and DOX [184,185] due to their outstanding features including biocompatibility, high encapsulation efficiency (EE), prolonged drug release, stability, targeted delivery and enhancing antitumor activity. Notably, lipid nanocarriers are also beneficial for codelivery of curcumin and DOX in different sorts of cancers, e.g., liver cancers. Lipid-based nanomaterials offer sustained release of curcumin and DOX that significantly enhances their antitumor activity. In vivo experiment also showed that curcumin- and DOX-loaded lipid NPs are capable of suppressing cancer growth [186]. It has been reported that curcumin- and DOX-loaded lipid NPs have more capability in apoptosis induction via enhancing caspase-3 expression and Bax/Bcl-2 ratio compared to curcumin and DOX alone [187].

The c-Myc is an oncogene pathway in promoting proliferation and invasion of cancer cells via interacting with other molecular pathways such as SOX4 [188]. The c-Myc signaling pathway is inhibited by curcumin- and DOX-loaded nanoparticles in HCC therapy [187]. A prerequisite for metastasis of cancer cells is angiogenesis induction. Vascular endothelial growth factor (VEGF) participates in cancer 
progression and migration via angiogenesis induction [189]. Downregulation of VEGF and P-gp occurs following exposing HCC cells to curcumin- and DOX-loaded lipid nanoparticles [187]. Self-assembled micelles are another option in codelivery of DOX and curcumin in cancer therapy. Polymeric micelles have a core-shell structure to entrap lipophilic active compounds in their hydrophobic core to enhance drug circulation in blood as results of their hydrophilic shell. Notably, polymeric micelles can selectively accumulate in cancer cells via enhanced permeability and retention (EPR) effect [190,191]. Polymeric micelles are able to enhance the cellular uptake of DOX through energy-dependent and caveolae-mediated endocytosis. These nanoparticles are able to suppress multidrug resistance (MDR) via CD44 targeting. Codelivery of curcumin and DOX by polymeric micelles significantly induces apoptosis in breast cancer cells [192]. Micelles not only can be applied for codelivery of curcumin and DOX, and enhancing their antitumor activity, but also can be applied for reducing DOX-mediated cardiotoxicity [193] Although cancer therapy is the main focus of this review, the aforementioned study provides the fact that micelles are potential nanocarriers for promoting bioavailability of curcumin and improving its therapeutic effects. In another study, self-assembly was employed for the local codelivery via peptide-based hydrogel, targeting head and neck cancer (Figure 5). The synergistic pharmacological effects were observed in codelivery of DOX and curcumin [194].
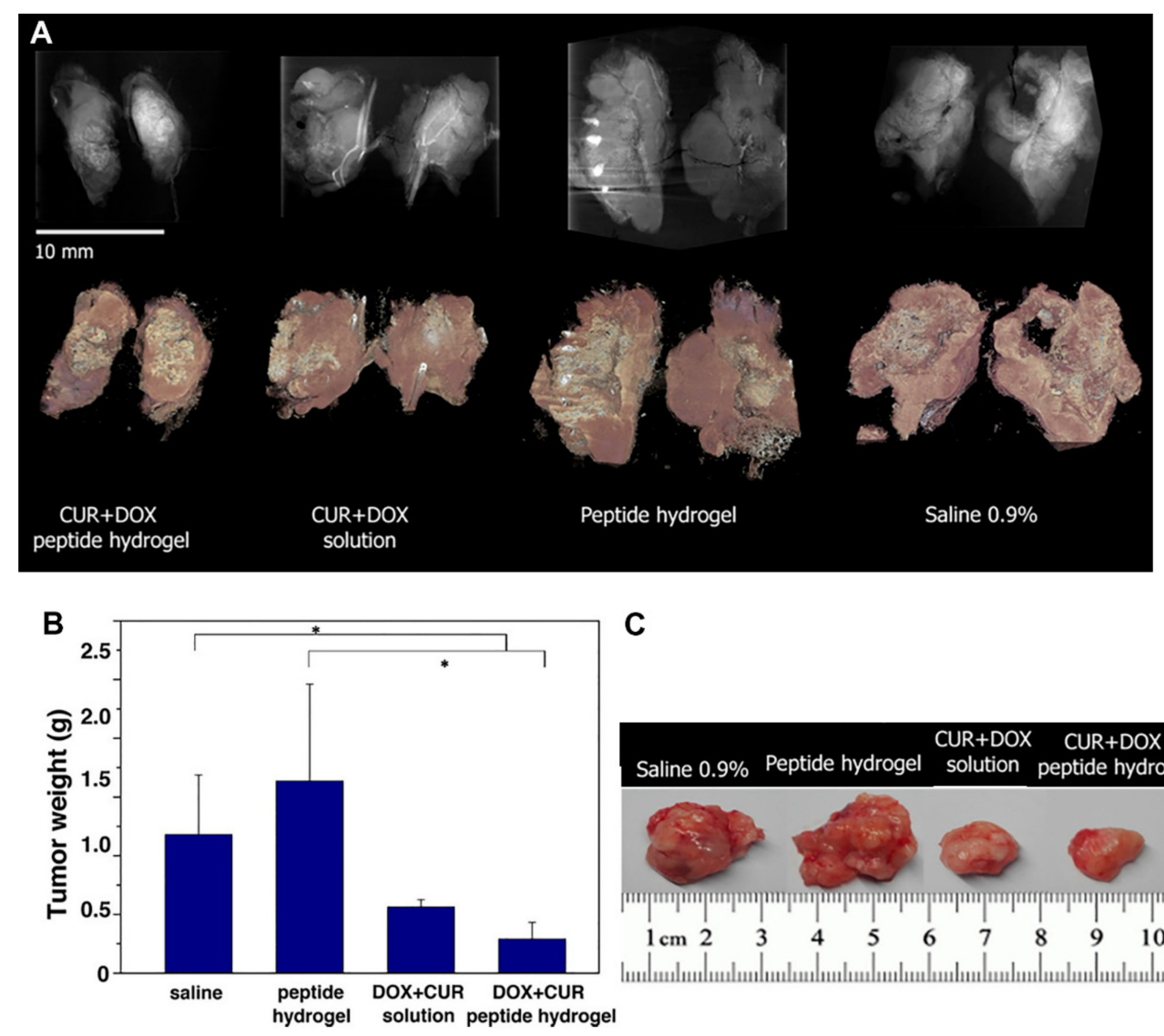

C

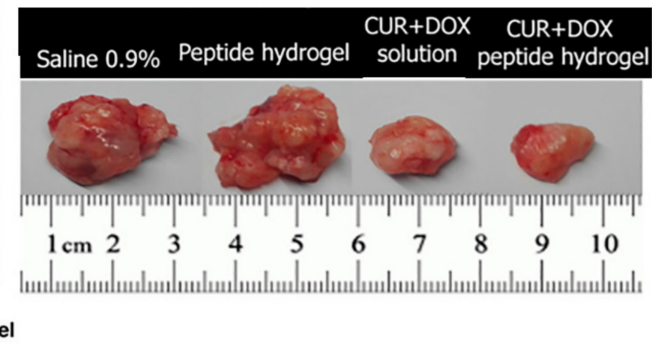

Figure 5. (A) Side-by-side comparison of the tumors studied by $\mu \mathrm{CT}$. Top row: Summation of intensity along the stack of CT slices ( $n$ slices $\approx 400$ ) showing density variations and overall dimensions of the tumors. Bottom row: 3D photorealistic rendering of the tumors. (B) Tumor weight ${ }^{*} p<0.05$ vs. control and blank treatment groups). (C) Representative images of tumors excised at the end point of the study on day 15. Reprinted with permission from [194], ACS Publications, 2019.

However, more progress can be made in promoting the efficacy of nanovehicles in curcumin and DOX delivery. In this regard, surface functionalization of micelles can be a good strategy. For instance, surface decorating with antibodies that selectively target overexpressed receptors on cancer cells is of importance. In light of this, glucose transporter-1 (GLUT-1), which is the responsible antibody for 
glucose uptake in cells, is a promising option [195]. Why is that? Although GLUT-1 is expressed on all kind of normal cells, its expression is substantially increased in cancer cells [196]. This is due to the need of cancer cells to glucose in providing enough energy for the Warburg effect [197]. Besides, GLUT-1 is distributed on the blood-brain barrier (BBB) plasma membrane and has overexpression on glioblastoma cells [198,199]. In order to selectively target glioblastoma cells, micelles have been modified with the GLUT-1 antibody. This is also of importance for promoting penetration of micelles via BBB. Overall, GLUT-1-modified micelles significantly elevate nuclear localization of DOX, and codelivery by curcumin has a synergistic effect. Apoptosis is induced by upregulation of caspase-3 and capase-7, and deep penetration into cancer cells occurs due to surface modification of micelles with GLUT-1 [200].

The tumor microenvironment plays a remarkable role in cancer progression. Enhanced levels of Th1 cells are associated with poor prognosis [201]. Nanomaterials can sense the tumor microenvironment for effective cancer therapy [202]. For instance, curcumin- and DOX-loaded liposomes can affect the Th1/Th2 axis in the tumor microenvironment for colon cancer therapy. Furthermore, apoptosis is induced by these nanocarriers and a decrease occurs in the migration of cancer cells [203]. Protein- and peptide-based nanostructures are also able to encapsulate small molecules with selective targeting of tumor cells and tissues [204-207].

NCA ( $\alpha$-amino acid- $N$-carboxyanhydrides and $\alpha$-amino acid) ring-opening polymerization is an affordable method in nanotechnology [208]. The fabricated polyamino acid by this method is biodegradable and can undergo metabolism in a normal metabolic way that is of importance for its biocompatibility [208]. Recently, polypeptide nanocarriers have been applied for codelivery of curcumin and DOX in lymphoma treatment. Curcumin and DOX demonstrate a synergistic effect in apoptosis induction in lymphoma cells and using polypeptide nanocarriers significantly promotes their efficiency in apoptosis stimulation. Furthermore, curcumin- and DOX-loaded polypeptide nanocarriers were able to exert effect on non-coding RNAs in lymphoma therapy. Curcumin- and DOX-loaded polypeptide nanocarriers significantly reduce expression of oncogene miRNAs such as miRNA-21 and miRNA-199a, while they increase expression of oncosuppressor miRNAs including miRNA-98 and miRNA-200c [209].

One of the features of the tumor microenvironment is its mild $\mathrm{pH}$. This is beneficial for designing smart nanocarriers that can release curcumin and DOX in tumor site $(\mathrm{pH}=5)[210,211]$. Furthermore, nanoparticles can be designed in selective targeting of receptors that undergo upregulation in cancer cells. Urokinase plasminogen activator receptor (uPAR) demonstrates overexpression in different cancer cells [212-214]. Recently, a smart pH-sensitive decorated with U11 peptide has been developed for targeted delivery of curcumin and DOX in lung cancer treatment. This nanocarrier is able to selective target lung cancer cells that overexpress uPAR. Furthermore, it releases curcumin and DOX in the $\mathrm{pH}$ of 5 that is similar to the $\mathrm{pH}$ of the tumor microenvironment. These excellent features lead to an increase in tumor accumulation of curcumin and DOX, and high cytotoxicity against cancer cells [215].

Stimuli-responsive prodrug nanoparticles have opened a new window in the production of smart and potential drug delivery systems. In this method, a small drug molecule is conjugated to a macromolecule. During circulation in blood, prodrug remains at its inactive form, while it is activated at the tumor site $[216,217]$. The $\mathrm{pH}$-sensitive prodrug nanoparticles have been designed for codelivery of curcumin and DOX in cancer therapy. These antitumor-loaded nanoparticles demonstrate sustained circulation in blood and promote penetration to cancer cells. This increase in local drug accumulation results in enhanced antitumor activity of curcumin and DOX against cancer cells [218].

Noteworthy, nanocarriers not only promote antitumor activity of curcumin and DOX against cancer cells, but also are beneficial in preventing chemoresistance [219]. To effectively suppress the metastasis of cancer cells, delivery of curcumin and DOX to tumor vasculatures is of importance. This leads to inhibition of angiogenesis and disrupting cancer invasion. RGDK-lipopeptide is suggested to be a promising candidate for selective targeting of tumor vasculature [220]. For this reason, liposomes have been modified with RGDK-lipopeptide. These nanocarriers are able to deliver curcumin and DOX to tumor vasculature and demonstrate high cellular uptake due to the 
presence of RGDK-lipopeptide. After accumulation in cancer cells, curcumin and DOX suppress tumor progression via the downregulating TGF-b signaling pathway [221]. This study demonstrates how surface modification of nanoparticle is in favor of promoting cell internalization of curcumin and DOX and enhancing their antitumor activity.

As curcumin suffers from poor bioavailability and DOX has adverse effects, using nanocarriers can provide targeted delivery of these active compounds associated with an increase in their effectiveness Intracellular accumulation of DOX and curcumin enhances after using nanoencapsulant for their codelivery. The chemoresistance is prevented, since nanoparticles provide sustained release of curcumin and DOX. Smart nanomaterials (e.g., pH-sensitive and redox-sensitive nanoparticles) can be applied for targeted delivery of curcumin and DOX, to release their cargo in response to the tumor microenvironment. Besides, the surface of nanoparticles can be modified by receptors and ligands (such as hyaluronic acid and RGD) to promote accumulation in cancer cells (Figure 6) [222-234]. In Table 3, different nanocarriers applied for codelivery of curcumin and DOX are described. Besides, encapsulation efficiency, zeta potential and major outcomes of the experiments are provided in Table 3 to shed some light on the application of nanostructures for DOX and curcumin codelivery.

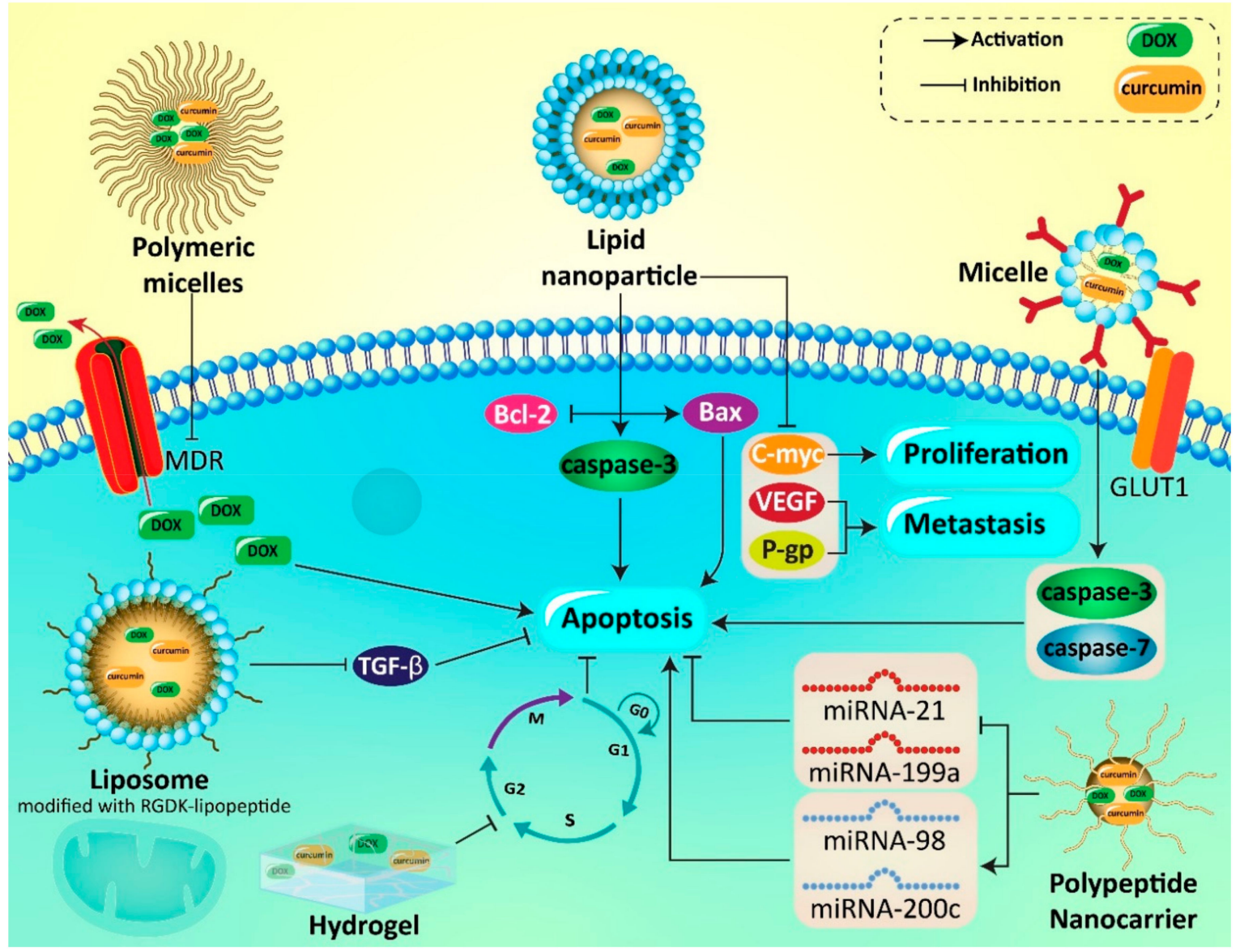

Figure 6. Curcumin- and DOX-loaded nanovehicles in effective cancer chemotherapy. DOX, doxorubicin; GLUT1, glucose transporter 1; VEGF, vascular endothelial growth factor; P-gp, P-glycoprotein; miRNA, microRNA; MDR, multidrug resistance; TGF- $\beta$, transforming growth factor- $\beta$. 
Table 3. Codelivery of curcumin and doxorubicin in providing effective cancer chemotherapy.

\begin{tabular}{|c|c|c|c|c|c|c|c|}
\hline Nanocarrier & In Vitro/In Vivo & Cell Line/Animal Model & $\begin{array}{l}\text { Encapsulation } \\
\text { Efficiency (\%) }\end{array}$ & Particle Size (nm) & $\begin{array}{l}\text { Zeta Potential } \\
(\mathrm{mV})\end{array}$ & Remarks & Refs \\
\hline Liposome & In Vitro & B16F10 cells & $\begin{array}{l}100 \text { (DOX) } 86 \\
\text { (curcumin) }\end{array}$ & $190-230$ & $2-4$ & $\begin{array}{l}\text { Surface modification of liposomes } \\
\text { with RGDK promotes their } \\
\text { cellular uptake } \\
\text { Enhancing antitumor activity by } \\
2-3 \text { folds }\end{array}$ & [221] \\
\hline Polymeric nanoparticles & In Vitro & HepG 2 and HeLa cells & $\begin{array}{c}18.35 \text { (DOX) } 91 \\
\text { (curcumin) }\end{array}$ & 183.5 & -0.68 & $\begin{array}{c}\text { Possessing pH sensitivity } \\
\text { capability } \\
\text { Being inactive at blood circulation } \\
\text { Activation at tumor site } \\
\text { Enhancing antitumor activity }\end{array}$ & [218] \\
\hline Polymeric nanoparticles & In Vitro & HUVEC cells and MCF-7/ADR cells & 92 & $115-135$ & 0.41 & $\begin{array}{c}\text { High drug loading } \\
\text { Hemodynamic stability } \\
\text { Intracellular accumulation } \\
\text { Suppressing cancer progression }\end{array}$ & [235] \\
\hline Polymeric nanoparticles & In Vitro In Vivo & $\begin{array}{c}\text { NIH-3T3 (mouse embryonic } \\
\text { fibroblast cells), HeLa (human } \\
\text { cervical cancer cells), NCI-H460 } \\
\text { (Human lung carcinoma cells), and } \\
\text { HFL1 (Human normal lung cells) }\end{array}$ & $23-53$ & $180-220$ & $10-15$ & $\begin{array}{c}\text { Apoptosis stimulation in resistant } \\
\text { cancer cells } \\
\text { DNA fragmentation } \\
\text { Enhancing bioavailability and } \\
\text { antitumor activity }\end{array}$ & [236] \\
\hline Micelle & $\begin{array}{l}\text { In Vitro } \\
\text { In Vivo }\end{array}$ & $\begin{array}{c}\mathrm{H} 9 \mathrm{C} 2 \text { cells } \\
\text { tumor-bearing mice }\end{array}$ & $90.6-99.8$ & $90.6-120$ & -0.13 to -2.34 & $\begin{array}{c}\text { High encapsulation efficiency } \\
\text { and drug loading } \\
\text { Sustained drug release } \\
\text { Elevating DOX accumulation in } \\
\text { cancer cells } \\
\text { Providing a delay in cancer } \\
\text { growth }\end{array}$ & [193] \\
\hline Micelle & In Vitro & U87MG cells & - & 14.4 to 14.8 & -4.2 to -4.4 & $\begin{array}{c}\text { Apoptosis induction via } \\
\text { caspase-3 and caspase-7 } \\
\text { upregulation } \\
\text { Deep internalization via GLUT-1 } \\
\text { Decreasing cancer viability }\end{array}$ & [200] \\
\hline Polymeric micelle & In Vitro & HepG2 and HUVEC cells & $\begin{array}{c}90.9 \text { (DOX) } \\
70.7 \text { (curcumin) }\end{array}$ & $80-110$ & -0.5 to +10 & $\begin{array}{l}\text { Redox-responsive drug release } \\
\text { Internalization through } \\
\text { endocytosis } \\
\text { Providing a synergistic effect and } \\
\text { enhancing antitumor activity }\end{array}$ & [237] \\
\hline
\end{tabular}


Table 3. Cont

\begin{tabular}{|c|c|c|c|c|c|c|c|}
\hline Nanocarrier & In Vitro/In Vivo & Cell Line/Animal Model & $\begin{array}{l}\text { Encapsulation } \\
\text { Efficiency (\%) }\end{array}$ & Particle Size (nm) & $\begin{array}{l}\text { Zeta Potential } \\
(\mathrm{mV})\end{array}$ & Remarks & Refs \\
\hline Polymeric micelles & In Vitro & MCF-7 cells & - & $164.2-190$ & - & $\begin{array}{l}\text { Enhanced cellular uptake due to } \\
\text { EPR effect } \\
\text { Elevating cytotoxicity against } \\
\text { cancer cells }\end{array}$ & [139] \\
\hline Micelle & In Vitro & MDA-MB-231 cells & $\begin{array}{c}94.69 \text { (DOX) } \\
99.97 \text { (curcumin) }\end{array}$ & 60 & -16.4 & $\begin{array}{l}\text { Exerting synergistic effect } \\
\text { Apoptosis induction }\end{array}$ & [238] \\
\hline Selenium nanoparticles & $\begin{array}{l}\text { In Vitro } \\
\text { In Vivo }\end{array}$ & HCT116 cells Tumor-bearing mice & - & $202-240$ & -31 to -37 & $\begin{array}{c}\text { Increasing ROS levels } \\
\text { Disrupting mitochondrial } \\
\text { homeostasis } \\
\text { Triggering apoptosis and cell } \\
\text { cycle arrest } \\
\text { Suppressing metastasis via EMT } \\
\text { and NF-kB downregulation } \\
\text { Autophagy inhibition } \\
\text { Promoting antitumor activity }\end{array}$ & [239] \\
\hline Solid lipid nanoparticles & In Vivo & Hodgkin's lymphoma in mice & - & 125.2 & -19.4 & $\begin{array}{c}\text { Promoting curcumin } \\
\text { bioavailability } \\
\text { Reducing cancer growth and } \\
\text { viability } \\
\text { Apoptosis induction via XIAP } \\
\text { and Mcl-1 downregulation } \\
\text { Ameliorating inflammation by } \\
\text { reducing pro-inflammatory } \\
\text { cytokines including IL-6 and } \\
\text { TNF- } \alpha\end{array}$ & [240] \\
\hline Solid lipid nanoparticles & $\begin{array}{l}\text { In Vitro } \\
\text { In Vivo }\end{array}$ & $\begin{array}{l}\text { Human MCF-7 cells, human TNBC } \\
\text { MDA-MB-231 and murine mammary } \\
\text { cancer JC cells } \\
\text { Tumor xenograft }\end{array}$ & - & - & - & $\begin{array}{l}\text { Enhancing cytotoxicity against } \\
\text { cancer cells by 5-10 folds } \\
\text { Inhibition of NF-kB signaling } \\
\text { pathway and subsequent } \\
\text { decrease in P-gp expression } \\
\text { Increasing accumulation of } \\
\text { antitumor agents in cancer cells }\end{array}$ & [241] \\
\hline $\begin{array}{l}\text { Mesoporous silica } \\
\text { nanoparticles }\end{array}$ & In Vitro & MCF-7 cells & - & - & - & $\begin{array}{c}\text { Localization in cytoplasmic } \\
\text { vesicles } \\
\text { Triggering apoptosis via capase-6, } \\
-9 \text { and }-12 \text { upregulation } \\
\text { Activation of PTEN and CHOP } \\
\text { for stimulating apoptosis } \\
\text { Disrupting mitochondrial } \\
\text { homeostasis } \\
\text { Autophagy induction by } \\
\text { nanoparticles }\end{array}$ & [242] \\
\hline
\end{tabular}




\section{Conclusions and Remarks}

Curcumin can be coapplied with DOX in promoting its antitumor activity. Curcumin potentiates the antitumor activity of DOX in a time- and dose-dependent manner. In enhancing the antitumor activity of DOX, curcumin upregulates expression of Bax, caspase-9, p53 and p21, while it reduces expression of Bcl-2 to stimulate apoptosis and promote the efficacy of DOX in chemotherapy. Besides, the metastasis of cancer cells is also negatively affected by curcumin in promoting DOX efficacy via MMP-2 downregulation and TIMP-1 upregulation. Curcumin inhibits EMT via downregulating TGF- $\beta$ and PI3K/Akt signaling networks, leading to an increase in sensitivity of cancer cells to DOX chemotherapy.

Notably, in potentiating antitumor activity of DOX, curcumin can be coadministered with $\mathrm{Zn}$ to improve gut dysbiosis, resulting in an enhancement in efficacy of DOX in chemotherapy. The drug transporters (P-gp) are inhibited by curcumin in promoting DOX sensitivity. In addition to drug transporters, molecular pathways that are responsible for cancer progression, are affected by curcumin in reversing DOX resistance. Akt, JNK, AP-1 and NF- $\mathrm{kB}$ are among the oncogene pathways that are downregulated by curcumin. Besides, curcumin reduces expression of DNA repair enzymes including MGMT, DNA-PK, ERCC-1, Ku70 and Ku80 in promoting DOX sensitivity.

A variety of experiments have evaluated protective effects of curcumin against DOX-mediated cardiotoxicity. Gut dysbiosis occurs following DOX administration and curcumin improves this condition to provide proper function of heart. Furthermore, oxidative stress, inflammation and DNA fragmentation and apoptosis are prevented by curcumin in alleviation of DOX-mediated cardiotoxicity.

Application of NPs significantly enhances curcumin bioavailability and its therapeutic effects ameliorating DOX-mediated cardiotoxicity. Noteworthy, according to poor bioavailability of curcumin and DOX, nanomaterials such as polymeric NPs, liposomes, micelles and nanogels and inorganic nanostructures (e.g., metal/metal oxide nanocompounds) have been designed for codelivery of DOX and curcumin. These nanocarriers significantly promote cell internalization of DOX and curcumin, resulting in improved antitumor activity. Furthermore, smart NPs such as $\mathrm{pH}$-sensitive ones have been designed for drug release at the tumor microenvironment. This review article revealed that curcumin is a potential adjuvant for polychemotherapy with DOX, and based on the safety of curcumin, clinical studies can begin evaluating efficiency of this regime in the treatment of cancer patients.

Author Contributions: M.A., P.M. and A.P.K. contributed to article design and concept. A.Z. (Ali Zarrabi) performed software and drawing high quality figures. M.A., F.H., A.Z. (Amirhossein Zabolian) and H.S. participated in writing. Sections 1-4. M.B., N.A., A.K.B., K.H., H.K. and H.L.A. wrote Sections 5-7. All authors were involved in writing and revising conclusion. All authors have read and agreed to the published version of the manuscript.

Funding: This research is funded by grants from the National Medical Research Council Singapore (grant number NMRC/OFIRG/0020/2016) to A.P.K. The National Research Foundation Singapore and the Singapore Ministry of Education under its Research Centers of Excellence initiative to Cancer Science Institute of Singapore; National University of Singapore also supported A.P.K. for this research.

Conflicts of Interest: The authors declare no conflict of interest.

\section{Abbreviations}

$\begin{array}{ll}\text { ROS } & \text { reactive oxygen species } \\ \text { EMT } & \text { epithelial-to-mesenchymal transition } \\ \text { miRNA } & \text { microRNA } \\ \text { PI3K } & \text { phosphatidylinositol 3-kinase } \\ \text { Akt } & \text { protein kinase-B } \\ \text { NF-kB } & \text { nuclear factor-kappaB } \\ \text { HCC } & \text { hepatocellular carcinoma } \\ \text { P-gp } & \text { P-glycoprotein } \\ \text { MDR1 } & \text { multidrug resistance 1 } \\ \text { Nrf2 } & \text { nuclear factor erythroid 2-related factor 2 }\end{array}$




$\begin{array}{ll}\text { TGF- } \beta 1 & \text { transforming growth factor-beta 1 } \\ \text { DOX } & \text { doxorubicin } \\ \text { TFF3 } & \text { trefoil factor } 3 \\ \text { SphK1 } & \text { sphingosine kinase 1 } \\ \text { OS } & \text { osteosarcoma } \\ \text { GSH } & \text { glutathione } \\ \text { SOD } & \text { superoxide dismutase } \\ \text { MDH } & \text { malondialdehyde } \\ \text { ECM } & \text { extracellular matrix } \\ \text { TIMPs } & \text { tissue inhibitors of metalloproteinases } \\ \text { EMT } & \text { epithelial-to-mesenchymal transition } \\ \text { ZnCM-SD } & \text { curcumin-Zn solid dispersion } \\ \text { ABC } & \text { ATP-binding cassette } \\ \text { ABCB4 } & \text { ABC sub-family B member 4 } \\ \text { EGCG } & \text { epigallocatechin gallate } \\ \text { S100A8 } & \text { S100 calcium-binding protein A8 } \\ \text { AP-1 } & \text { activator protein-1 } \\ \text { CAT } & \text { catalase } \\ \text { TNF- } \alpha & \text { tumor necrosis factor- } \alpha \\ \text { IL-1 } \beta & \text { interleukin-1 } \beta \\ \text { CAR } & \text { carvacrol } \\ \text { PiC } & \text { mitochondrial phosphate carrier } \\ \text { MSNs } & \text { mesoporous silica nanoparticles } \\ \text { EE } & \text { encapsulation efficiency } \\ \text { VEGF } & \text { vascular endothelial growth factor } \\ \text { EPR } & \text { enhanced permeability and retention } \\ \text { MDR } & \text { multidrug resistance } \\ \text { GLUT-1 } & \text { glucose transporter-1 } \\ \text { BBB } & \text { blood-brain barrier } \\ \text { uPAR } & \text { urokinase plasminogen activator receptor } \\ \text { HO-1 } & \text { heme oxygenase-1 } \\ \text { NQO1 } & \end{array}$

\section{References}

1. Zhang, Q.; Zhang, Z.Y.; Du, H.; Li, S.Z.; Tu, R.; Jia, Y.F.; Zheng, Z.; Song, X.M.; Du, R.L.; Zhang, X.D. DUB3 deubiquitinates and stabilizes NRF2 in chemotherapy resistance of colorectal cancer. Cell Death Differ. 2019, 26, 2300-2313. [CrossRef] [PubMed]

2. Liu, X.; Lu, Y.; Xu, Y.; Hou, S.; Huang, J.; Wang, B.; Zhao, J.; Xia, S.; Fan, S.; Yu, X.; et al. Exosomal transfer of miR-501 confers doxorubicin resistance and tumorigenesis via targeting of BLID in gastric cancer. Cancer Lett. 2019, 459, 122-134. [CrossRef] [PubMed]

3. Liang, Y.; Song, X.; Li, Y.; Su, P.; Han, D.; Ma, T.; Guo, R.; Chen, B.; Zhao, W.; Sang, Y.; et al. circKDM4C suppresses tumor progression and attenuates doxorubicin resistance by regulating miR-548p/PBLD axis in breast cancer. Oncogene 2019, 38, 6850-6866. [CrossRef] [PubMed]

4. Mu, Y.; Wu, G.; Su, C.; Dong, Y.; Zhang, K.; Li, J.; Sun, X.; Li, Y.; Chen, X.; Feng, C. pH-sensitive amphiphilic chitosan-quercetin conjugate for intracellular delivery of doxorubicin enhancement. Carbohydr. Polym. 2019, 223, 115072. [CrossRef]

5. Soltantabar, P.; Calubaquib, E.L.; Mostafavi, E.; Biewer, M.C.; Stefan, M.C. Enhancement of Loading Efficiency by Coloading of Doxorubicin and Quercetin in Thermoresponsive Polymeric Micelles. Biomacromolecules 2020, 21, 1427-1436. [CrossRef]

6. Gökçe Kütük, S.; Gökçe, G.; Kütük, M.; Gürses Cila, H.E.; Nazıroğlu, M. Curcumin enhances cisplatin-induced human laryngeal squamous cancer cell death through activation of TRPM2 channel and mitochondrial oxidative stress. Sci. Rep. 2019, 9, 17784. [CrossRef] 
7. Paciello, F.; Rita Fetoni, A.; Mezzogori, D.; Rolesi, R.; Di Pino, A.; Paludetti, G.; Grassi, C.; Troiani, D. The dual role of curcumin and ferulic acid in counteracting chemoresistance and cisplatin-induced ototoxicity. Sci. Rep. 2020, 10, 1063. [CrossRef]

8. Jiang, X.; Huang, Y. Curcumin Derivative C086 Combined with Cisplatin Inhibits Proliferation of Osteosarcoma Cells. Med. Sci. Monit. 2020, 26, e924507. [CrossRef]

9. Wang, W.; Shanmugam, M.K.; Xiang, P.; Yam, T.Y.A.; Kumar, V.; Chew, W.S.; Chang, J.K.; Ali, M.Z.B.; Reolo, M.J.Y.; Peh, Y.X.; et al. Sphingosine 1-Phosphate Receptor 2 Induces Otoprotective Responses to Cisplatin Treatment. Cancers 2020, 12, 211. [CrossRef]

10. Aktaş, I.; Özmen, Ö.; Tutun, H.; Yalçın, A.; Türk, A. Artemisinin attenuates doxorubicin induced cardiotoxicity and hepatotoxicity in rats. Biotech. Histochem. 2020, 95, 121-128. [CrossRef]

11. Wang, Y.; Chao, X.; Ahmad, F.U.D.; Shi, H.; Mehboob, H.; Hassan, W. Phoenix dactylifera Protects against Doxorubicin-Induced Cardiotoxicity and Nephrotoxicity. Cardiol. Res. Pr. 2019, 2019, 7395239. [CrossRef] [PubMed]

12. Georgakopoulos, P.; Kyriakidis, M.; Perpinia, A.; Karavidas, A.; Zimeras, S.; Mamalis, N.; Kouvela, M.; Charpidou, A. The Role of Metoprolol and Enalapril in the Prevention of Doxorubicin-induced Cardiotoxicity in Lymphoma Patients. Anticancer Res. 2019, 39, 5703-5707. [CrossRef] [PubMed]

13. El-Gizawy, M.M.; Hosny, E.N.; Mourad, H.H.; Abd-El Razik, A.N. Curcumin nanoparticles ameliorate hepatotoxicity and nephrotoxicity induced by cisplatin in rats. Naunyn Schmiedebergs Arch. Pharm. 2020, 393, 1941-1953. [CrossRef] [PubMed]

14. Negrette-Guzmán, M. Combinations of the antioxidants sulforaphane or curcumin and the conventional antineoplastics cisplatin or doxorubicin as prospects for anticancer chemotherapy. Eur. J. Pharm. 2019, 859, 172513. [CrossRef]

15. Navya, P.N.; Madhyastha, H.; Madhyastha, R.; Nakajima, Y.; Maruyama, M.; Srinivas, S.P.; Jain, D.; Amin, M.H.; Bhargava, S.K.; Daima, H.K. Single step formation of biocompatible bimetallic alloy nanoparticles of gold and silver using isonicotinylhydrazide. Mater. Sci. Eng. C 2019, 96, 286-294. [CrossRef]

16. Sahoo, P.R.; Madhyastha, H.; Madhyastha, R.; Maruyama, M.; Nakajima, Y. Recent Progress in Nanotheranostic Medicine. Nanopharm. Princ. Appl. 2020, 3, 317-334.

17. Sanjana, S.; Medha, M.; Meghna, M.; Shruthi, T.; Srinivas, S.; Madhyastha, H.; Navya, P.; Daima, H.K. Enzyme immobilization on quercetin capped gold and silver nanoparticles for improved performance. Mater. Today Proc. 2019, 10, 92-99. [CrossRef]

18. Khan, M.M.; Madni, A.; Tahir, N.; Parveen, F.; Khan, S.; Jan, N.; Ali, A.; Abdurrahim, M.; Farooq, U.; Khan, M.I. Co-Delivery of Curcumin and Cisplatin to Enhance Cytotoxicity of Cisplatin Using Lipid-Chitosan Hybrid Nanoparticles. Int. J. Nanomed. 2020, 15, 2207-2217. [CrossRef]

19. Zhao, M.D.; Li, J.Q.; Chen, F.Y.; Dong, W.; Wen, L.J.; Fei, W.D.; Zhang, X.; Yang, P.L.; Zhang, X.M.; Zheng, C.H. Co-Delivery of Curcumin and Paclitaxel by "Core-Shell" Targeting Amphiphilic Copolymer to Reverse Resistance in the Treatment of Ovarian Cancer. Int. J. Nanomed. 2019, 14, 9453-9467. [CrossRef]

20. Zielińska, A.; Alves, H.; Marques, V.; Durazzo, A.; Lucarini, M.; Alves, T.F.; Morsink, M.; Willemen, N.; Eder, P.; Chaud, M.V. Properties, Extraction Methods, and Delivery Systems for Curcumin as a Natural Source of Beneficial Health Effects. Medicina 2020, 56, 336. [CrossRef]

21. Alven, S.; Aderibigbe, B.A. Efficacy of Polymer-Based Nanocarriers for Co-Delivery of Curcumin and Selected Anticancer Drugs. Nanomaterials 2020, 10, 1556. [CrossRef] [PubMed]

22. Islam, S.R.; Siddiqua, T.J. Functional foods in cancer prevention and therapy: Recent epidemiological findings. In Functional Foods in Cancer Prevention and Therapy; Elsevier: Amsterdam, The Netherlands, 2020; pp. 405-433.

23. Tang, F.; Ling, C. Curcumin ameliorates chronic obstructive pulmonary disease by modulating autophagy and endoplasmic reticulum stress through regulation of SIRT1 in a rat model. J. Int. Med. Res. 2019, 47, 4764-4774. [CrossRef] [PubMed]

24. Voulgaropoulou, S.D.; van Amelsvoort, T.; Prickaerts, J.; Vingerhoets, C. The effect of curcumin on cognition in Alzheimer's disease and healthy aging: A systematic review of pre-clinical and clinical studies. Brain Res. 2019, 1725, 146476. [CrossRef]

25. Hirata, Y.; Ito, Y.; Takashima, M.; Yagyu, K.; Oh-Hashi, K.; Suzuki, H.; Ono, K.; Furuta, K.; Sawada, M. Novel Oxindole-Curcumin Hybrid Compound for Antioxidative Stress and Neuroprotection. ACS Chem. Neurosci. 2020, 11, 76-85. [CrossRef] [PubMed] 
26. Motawi, T.K.; Sadik, N.A.H.; Hamed, M.A.; Ali, S.A.; Khalil, W.K.B.; Ahmed, Y.R. Potential therapeutic effects of antagonizing adenosine A(2A) receptor, curcumin and niacin in rotenone-induced Parkinson's disease mice model. Mol. Cell Biochem. 2020, 465, 89-102. [CrossRef] [PubMed]

27. Tamddoni, A.; Mohammadi, E.; Sedaghat, F.; Qujeq, D.; As'Habi, A. The anticancer effects of curcumin via targeting the mammalian target of rapamycin complex 1 (mTORC1) signaling pathway. Pharmacol. Res. 2020, 156, 104798. [CrossRef]

28. Baldi, A.; De Luca, A.; Maiorano, P.; D'Angelo, C.; Giordano, A. Curcumin as an Anticancer Agent in Malignant Mesothelioma: A Review. Int. J. Mol. Sci. 2020, 21, 1839. [CrossRef]

29. Bagheri, H.; Ghasemi, F.; Barreto, G.E.; Rafiee, R.; Sathyapalan, T.; Sahebkar, A. Effects of curcumin on mitochondria in neurodegenerative diseases. Biofactors 2020, 46, 5-20. [CrossRef]

30. Ba, P.; Xu, M.; Yu, M.; Li, L.; Duan, X.; Lv, S.; Fu, G.; Yang, J.; Yang, P.; Yang, C.; et al. Curcumin suppresses the proliferation and tumorigenicity of Cal27 by modulating cancer associated fibroblasts of TSCC. Oral. Dis. 2020. [CrossRef]

31. Mani, J.; Fleger, J.; Rutz, J.; Maxeiner, S.; Bernd, A.; Kippenberger, S.; Zöller, N.; Chun, F.K.; Relja, B.; Juengel, E.; et al. Curcumin combined with exposure to visible light blocks bladder cancer cell adhesion and migration by an integrin dependent mechanism. Eur. Rev. Med. Pharm. Sci. 2019, 23, 10564-10574. [CrossRef]

32. Wang, X.; Chang, X.; Zhan, H.; Zhang, Q.; Li, C.; Gao, Q.; Yang, M.; Luo, Z.; Li, S.; Sun, Y. Curcumin and Baicalin ameliorate ethanol-induced liver oxidative damage via the Nrf2/HO-1 pathway. J. Food Biochem. 2020, 44, e13425. [CrossRef] [PubMed]

33. Al-Dossari, M.H.; Fadda, L.M.; Attia, H.A.; Hasan, I.H.; Mahmoud, A.M. Curcumin and Selenium Prevent Lipopolysaccharide/Diclofenac-Induced Liver Injury by Suppressing Inflammation and Oxidative Stress. Biol. Trace Elem. Res. 2020, 196, 173-183. [CrossRef] [PubMed]

34. Sudirman, S.; Lai, C.S.; Yan, Y.L.; Yeh, H.I.; Kong, Z.L. Histological evidence of chitosan-encapsulated curcumin suppresses heart and kidney damages on streptozotocin-induced type-1 diabetes in mice model. Sci. Rep. 2019, 9, 15233. [CrossRef] [PubMed]

35. Liu, B.; Cui, L.S.; Zhou, B.; Zhang, L.L.; Liu, Z.H.; Zhang, L. Monocarbonyl curcumin analog A2 potently inhibits angiogenesis by inducing ROS-dependent endothelial cell death. Acta Pharm. Sin. 2019, 40, 1412-1423. [CrossRef] [PubMed]

36. Abo-Zaid, M.A.; Shaheen, E.S.; Ismail, A.H. Immunomodulatory effect of curcumin on hepatic cirrhosis in experimental rats. J. Food Biochem. 2020, 44, e13219. [CrossRef]

37. Nayak, D.; Tripathi, N.; Kathuria, D.; Siddharth, S.; Nayak, A.; Bharatam, P.V.; Kundu, C. Quinacrine and curcumin synergistically increased the breast cancer stem cells death by inhibiting ABCG2 and modulating DNA damage repair pathway. Int. J. Biochem. Cell Biol. 2020, 119, 105682. [CrossRef]

38. Li, Y.; Tian, L.; Sun, D.; Yin, D. Curcumin ameliorates atherosclerosis through upregulation of miR-126. J. Cell Physiol. 2019, 234, 21049-21059. [CrossRef]

39. Ghelani, H.; Razmovski-Naumovski, V.; Chang, D.; Nammi, S. Chronic treatment of curcumin improves hepatic lipid metabolism and alleviates the renal damage in adenine-induced chronic kidney disease in Sprague-Dawley rats. BMC Nephrol. 2019, 20, 431. [CrossRef]

40. Hadi, A.; Pourmasoumi, M.; Ghaedi, E.; Sahebkar, A. The effect of Curcumin/Turmeric on blood pressure modulation: A systematic review and meta-analysis. Pharm. Res. 2019, 150, 104505. [CrossRef]

41. Liczbiński, P.; Michałowicz, J.; Bukowska, B. Molecular mechanism of curcumin action in signaling pathways: Review of the latest research. Phytother. Res. 2020. [CrossRef]

42. Wahlström, B.; Blennow, G. A study on the fate of curcumin in the rat. Acta Pharmacol. Toxicol. 1978, 43, 86-92.

43. Hsieh, C. Phase I clinical trial of curcumin, a chemopreventive agent, in patients with high-risk or pre-malignant lesions. Anticancer Res. 2001, 21, 2859-2900.

44. Sharma, R.A.; McLelland, H.R.; Hill, K.A.; Ireson, C.R.; Euden, S.A.; Manson, M.M.; Pirmohamed, M.; Marnett, L.J.; Gescher, A.J.; Steward, W.P. Pharmacodynamic and pharmacokinetic study of oral Curcuma extract in patients with colorectal cancer. Clin. Cancer Res. 2001, 7, 1894-1900. [PubMed]

45. Sun, C.; Zhang, S.; Liu, C.; Liu, X. Curcumin Promoted miR-34a Expression and Suppressed Proliferation of Gastric Cancer Cells. Cancer Biother. Radiopharm. 2019, 34, 634-641. [CrossRef] 
46. Zhang, X.; Zhang, C.; Ren, Z.; Zhang, F.; Xu, J.; Zhang, X.; Zheng, H. Curcumin Affects Gastric Cancer Cell Migration, Invasion and Cytoskeletal Remodeling Through Gli1- $\beta$-Catenin. Cancer Manag. Res. 2020, 12 , 3795-3806. [CrossRef]

47. San, T.T.; Khaenam, P.; Prachayasittikul, V.; Sripa, B.; Kunkeaw, N.; Chan-On, W. Curcumin enhances chemotherapeutic effects and suppresses ANGPTL4 in anoikis-resistant cholangiocarcinoma cells. Heliyon 2020, 6, e03255. [CrossRef]

48. Chen, L.; Zhan, C.Z.; Wang, T.; You, H.; Yao, R. Curcumin Inhibits the Proliferation, Migration, Invasion, and Apoptosis of Diffuse Large B-Cell Lymphoma Cell Line by Regulating MiR-21/VHL Axis. Yonsei Med. J. 2020, 61, 20-29. [CrossRef]

49. Zhou, C.; Hu, C.; Wang, B.; Fan, S.; Jin, W. Curcumin Suppresses Cell Proliferation, Migration, and Invasion Through Modulating miR-21-5p/SOX6 Axis in Hepatocellular Carcinoma. Cancer Biother. Radiopharm. 2020. [CrossRef]

50. Gallardo, M.; Kemmerling, U.; Aguayo, F.; Bleak, T.C.; Muñoz, J.P.; Calaf, G.M. Curcumin rescues breast cells from epithelial-mesenchymal transition and invasion induced by anti-miR-34a. Int. J. Oncol. 2020, 56, 480-493. [CrossRef]

51. Shi, N.; Yu, H.; Chen, T. Inhibition of esophageal cancer growth through the suppression of PI3K/AKT/mTOR signaling pathway. Oncol. Targets 2019, 12, 7637-7647. [CrossRef]

52. Jiang, C.; Ma, Z.; Zhang, G.; Yang, X.; Du, Q.; Wang, W. CSNK2A1 Promotes Gastric Cancer Invasion Through the PI3K-Akt-mTOR Signaling Pathway. Cancer Manag. Res. 2019, 11, 10135-10143. [CrossRef] [PubMed]

53. Zhang, Z.; Lin, R.; Liu, Z.; Yan, T.; Xia, Y.; Zhao, L.; Lin, F.; Zhang, X.; Li, C.; Wang, Y. Curcumin analog, WZ37, promotes G2/M arrest and apoptosis of HNSCC cells through Akt/mTOR inhibition. Toxicol. Vitr. 2020, 65, 104754. [CrossRef] [PubMed]

54. Sak, K. Radiosensitizing Potential of Curcumin in Different Cancer Models. Nutr. Cancer 2020, 72, 1276-1289. [CrossRef] [PubMed]

55. Bolat, Z.B.; Islek, Z.; Demir, B.N.; Yilmaz, E.N.; Sahin, F.; Ucisik, M.H. Curcumin- and Piperine-Loaded Emulsomes as Combinational Treatment Approach Enhance the Anticancer Activity of Curcumin on HCT116 Colorectal Cancer Model. Front. Bioeng. Biotechnol. 2020, 8, 50. [CrossRef]

56. Zhang, L.; Tao, X.; Fu, Q.; Ge, C.; Li, R.; Li, Z.; Zhu, Y.; Tian, H.; Li, Q.; Liu, M.; et al. Curcumin inhibits cell proliferation and migration in NSCLC through a synergistic effect on the TLR4/MyD88 and EGFR pathways. Oncol. Rep. 2019, 42, 1843-1855. [CrossRef]

57. Epelbaum, R.; Schaffer, M.; Vizel, B.; Badmaev, V.; Bar-Sela, G. Curcumin and gemcitabine in patients with advanced pancreatic cancer. Nutr. Cancer 2010, 62, 1137-1141. [CrossRef]

58. Greil, R.; Greil-Ressler, S.; Weiss, L.; Schönlieb, C.; Magnes, T.; Radl, B.; Bolger, G.T.; Vcelar, B.; Sordillo, P.P. A phase 1 dose-escalation study on the safety, tolerability and activity of liposomal curcumin (Lipocurc $\left({ }^{\mathrm{TM}}\right)$ ) in patients with locally advanced or metastatic cancer. Cancer Chemother. Pharm. 2018, 82, 695-706. [CrossRef]

59. Dhillon, N.; Aggarwal, B.B.; Newman, R.A.; Wolff, R.A.; Kunnumakkara, A.B.; Abbruzzese, J.L.; Ng, C.S.; Badmaev, V.; Kurzrock, R. Phase II trial of curcumin in patients with advanced pancreatic cancer. Clin. Cancer Res. 2008, 14, 4491-4499. [CrossRef]

60. Pastorelli, D.; Fabricio, A.S.C.; Giovanis, P.; D’Ippolito, S.; Fiduccia, P.; Soldà, C.; Buda, A.; Sperti, C.; Bardini, R.; Da Dalt, G.; et al. Phytosome complex of curcumin as complementary therapy of advanced pancreatic cancer improves safety and efficacy of gemcitabine: Results of a prospective phase II trial. Pharm. Res. 2018, 132, 72-79. [CrossRef]

61. Guney Eskiler, G.; Sahin, E.; Deveci Ozkan, A.; Cilingir Kaya, O.T.; Kaleli, S. Curcumin induces DNA damage by mediating homologous recombination mechanism in triple negative breast cancer. Nutr. Cancer 2020, 72, 1057-1066. [CrossRef]

62. Zhou, X.; Jiao, D.; Dou, M.; Zhang, W.; Lv, L.; Chen, J.; Li, L.; Wang, L.; Han, X. Curcumin inhibits the growth of triple-negative breast cancer cells by silencing EZH2 and restoring DLC1 expression. J. Cell. Mol. Med. 2020, 24, 10648-10662. [CrossRef]

63. Tian, N.; Shangguan, W.; Zhou, Z.; Yao, Y.; Fan, C.; Cai, L. Lin28b is involved in curcumin-reversed paclitaxel chemoresistance and associated with poor prognosis in hepatocellular carcinoma. J. Cancer 2019, 10, 6074-6087. [CrossRef] [PubMed] 
64. Attia, Y.M.; El-Kersh, D.M.; Ammar, R.A.; Adel, A.; Khalil, A.; Walid, H.; Eskander, K.; Hamdy, M.; Reda, N.; Mohsen, N.E.; et al. Inhibition of aldehyde dehydrogenase-1 and p-glycoprotein-mediated multidrug resistance by curcumin and vitamin D3 increases sensitivity to paclitaxel in breast cancer. Chem. Biol. Interact. 2020, 315, 108865. [CrossRef] [PubMed]

65. Gao, J.; Fan, K.; Jin, Y.; Zhao, L.; Wang, Q.; Tang, Y.; Xu, H.; Liu, Z.; Wang, S.; Lin, J.; et al. PEGylated lipid bilayer coated mesoporous silica nanoparticles co-delivery of paclitaxel and curcumin leads to increased tumor site drug accumulation and reduced tumor burden. Eur. J. Pharm. Sci. 2019, 140, 105070. [CrossRef]

66. Hiremath, C.G.; Heggnnavar, G.B.; Kariduraganavar, M.Y.; Hiremath, M.B. Co-delivery of paclitaxel and curcumin to foliate positive cancer cells using Pluronic-coated iron oxide nanoparticles. Prog. Biomater. 2019, 8, 155-168. [CrossRef]

67. Maghmomeh, A.O.; El-Gayar, A.M.; El-Karef, A.; Abdel-Rahman, N. Arsenic trioxide and curcumin attenuate cisplatin-induced renal fibrosis in rats through targeting Hedgehog signaling. Naunyn Schmiedebergs Arch. Pharm. 2020, 393, 303-313. [CrossRef]

68. Li, L.; Chen, Y.; Jiao, D.; Yang, S.; Li, P. Protective Effect of Astaxanthin on Ochratoxin A-Induced Kidney Injury to Mice by Regulating Oxidative Stress-Related NRF2/KEAP1 Pathway. Molecules 2020, 25, 1386. [CrossRef]

69. Al Fayi, M.; Otifi, H.; Alshyarba, M.; Dera, A.A.; Rajagopalan, P. Thymoquinone and curcumin combination protects cisplatin-induced kidney injury, nephrotoxicity by attenuating NFKB, KIM-1 and ameliorating Nrf2/HO-1 signalling. J. Drug Target. 2020, 1-10. [CrossRef]

70. Zheng, Z.H.; You, H.Y.; Feng, Y.J.; Zhang, Z.T. LncRNA KCNQ1OT1 is a key factor in the reversal effect of curcumin on cisplatin resistance in the colorectal cancer cells. Mol. Cell Biochem. 2020. [CrossRef]

71. Ozawa-Umeta, H.; Kishimoto, A.; Imaizumi, A.; Hashimoto, T.; Asakura, T.; Kakeya, H.; Kanai, M. Curcumin $\beta$-D-glucuronide exhibits anti-tumor effects on oxaliplatin-resistant colon cancer with less toxicity in vivo. Cancer Sci. 2020, 111, 1785-1793. [CrossRef]

72. Lu, Y.; Wu, S.; Xiang, B.; Li, L.; Lin, Y. Curcumin Attenuates Oxaliplatin-Induced Liver Injury and Oxidative Stress by Activating the Nrf2 Pathway. Drug Des. Dev. Ther. 2020, 14, 73-85. [CrossRef] [PubMed]

73. Yi, L.T.; Dong, S.Q.; Wang, S.S.; Chen, M.; Li, C.F.; Geng, D.; Zhu, J.X.; Liu, Q.; Cheng, J. Curcumin attenuates cognitive impairment by enhancing autophagy in chemotherapy. Neurobiol. Dis. 2020, 136, 104715. [CrossRef] [PubMed]

74. Al-malky, H.S.; Al Harthi, S.E.; Osman, A.-M.M. Major obstacles to doxorubicin therapy: Cardiotoxicity and drug resistance. J. Oncol. Pharm. Pract. 2020, 26, 434-444. [CrossRef] [PubMed]

75. Morabito, A.; Gattuso, D.; Stani, S.C.; Fanelli, M.; Ferraù, F.; De Sio, L.; Castellana, M.A.; Lorusso, V.; Priolo, D.; Vitale, S. Safety and activity of the combination of pegylated liposomal doxorubicin and weekly docetaxel in advanced breast cancer. Breast. Cancer Res. Treat. 2004, 86, 249-258. [CrossRef]

76. Gabizon, A.; Shmeeda, H.; Barenholz, Y. Pharmacokinetics of pegylated liposomal doxorubicin. Clin. Pharmacokinet. 2003, 42, 419-436. [CrossRef]

77. Mohajeri, M.; Sahebkar, A. Protective effects of curcumin against doxorubicin-induced toxicity and resistance: A review. Crit. Rev. Oncol. Hematol. 2018, 122, 30-51. [CrossRef]

78. Perry, J.K.; Kannan, N.; Grandison, P.M.; Mitchell, M.D.; Lobie, P.E. Are trefoil factors oncogenic? Trends Endocrinol. Metab. 2008, 19, 74-81. [CrossRef]

79. Aamann, L.; Vestergaard, E.M.; Grønbæk, H. Trefoil factors in inflammatory bowel disease. World J. Gastroenterol. 2014, 20, 3223-3230. [CrossRef]

80. Choudhary, A.; Smitha, C.N.; Suresh, D.K. Trefoils: An unexplored natural protective shield of oral cavity. J. Oral. Biol. Craniofac Res. 2015, 5, 226-231. [CrossRef]

81. Poh, H.M.; Chiou, Y.S.; Chong, Q.Y.; Chen, R.M.; Rangappa, K.S.; Ma, L.; Zhu, T.; Kumar, A.P.; Pandey, V.; Lee, S.C.; et al. Inhibition of TFF3 Enhances Sensitivity-and Overcomes Acquired Resistance-to Doxorubicin in Estrogen Receptor-Positive Mammary Carcinoma. Cancers 2019, 11, 1528. [CrossRef]

82. Gault, C.R.; Obeid, L.M. Still benched on its way to the bedside: Sphingosine kinase 1 as an emerging target in cancer chemotherapy. Crit. Rev. Biochem. Mol. Biol. 2011, 46, 342-351. [CrossRef] [PubMed]

83. Sun, K.; Zhang, Y.; D’Alessandro, A.; Nemkov, T.; Song, A.; Wu, H.; Liu, H.; Adebiyi, M.; Huang, A.; Wen, Y.E.; et al. Sphingosine-1-phosphate promotes erythrocyte glycolysis and oxygen release for adaptation to high-altitude hypoxia. Nat. Commun. 2016, 7, 12086. [CrossRef] [PubMed] 
84. Cuvillier, O.; Ader, I.; Bouquerel, P.; Brizuela, L.; Gstalder, C.; Malavaud, B. Hypoxia, therapeutic resistance, and sphingosine 1-phosphate. Adv. Cancer Res. 2013, 117, 117-141. [CrossRef] [PubMed]

85. Ren, X.; Su, C. Sphingosine kinase 1 contributes to doxorubicin resistance and glycolysis in osteosarcoma. Mol. Med. Rep. 2020, 22, 2183-2190. [CrossRef]

86. Liu, C.; Xing, H.; Guo, C.; Yang, Z.; Wang, Y.; Wang, Y. MiR-124 reversed the doxorubicin resistance of breast cancer stem cells through STAT3/HIF-1 signaling pathways. Cell Cycle 2019, 18, 2215-2227. [CrossRef]

87. Zhou, Y.; Chen, E.; Tang, Y.; Mao, J.; Shen, J.; Zheng, X.; Xie, S.; Zhang, S.; Wu, Y.; Liu, H.; et al. miR-223 overexpression inhibits doxorubicin-induced autophagy by targeting FOXO3a and reverses chemoresistance in hepatocellular carcinoma cells. Cell Death Dis. 2019, 10, 843. [CrossRef]

88. Zhong, J.; Sun, P.; Xu, N.; Liao, M.; Xu, C.; Ding, Y.; Cai, J.; Zhang, Y.; Xie, W. Canagliflozin inhibits p-gp function and early autophagy and improves the sensitivity to the antitumor effect of doxorubicin. Biochem. Pharm. 2020, 175, 113856. [CrossRef]

89. Le, Y.; Kan, A.; Li, Q.J.; He, M.K.; Chen, H.L.; Shi, M. NAP1L1 is a prognostic biomarker and contribute to doxorubicin chemotherapy resistance in human hepatocellular carcinoma. Cancer Cell Int. 2019, 19, 228. [CrossRef]

90. Tan, X.; Liao, Z.; Zou, S.; Ma, L.; Wang, A. VASH2 Promotes Cell Proliferation and Resistance to Doxorubicin in Non-Small Cell Lung Cancer via AKT Signaling. Oncol. Res. 2020, 28, 3-11. [CrossRef]

91. Ma, W.; Yang, L.; Liu, H.; Chen, P.; Ren, H.; Ren, P. PAXX is a novel target to overcome resistance to doxorubicin and cisplatin in osteosarcoma. Biochem. Biophys. Res. Commun. 2020, 521, 204-211. [CrossRef]

92. Calcabrini, C.; Maffei, F.; Turrini, E.; Fimognari, C. Sulforaphane Potentiates Anticancer Effects of Doxorubicin and Cisplatin and Mitigates Their Toxic Effects. Front. Pharm. 2020, 11, 567. [CrossRef] [PubMed]

93. Zhang, X.; Hu, C.; Kong, C.Y.; Song, P.; Wu, H.M.; Xu, S.C.; Yuan, Y.P.; Deng, W.; Ma, Z.G.; Tang, Q.Z. FNDC5 alleviates oxidative stress and cardiomyocyte apoptosis in doxorubicin-induced cardiotoxicity via activating AKT. Cell Death Differ. 2020, 27, 540-555. [CrossRef] [PubMed]

94. Pan, J.A.; Tang, Y.; Yu, J.Y.; Zhang, H.; Zhang, J.F.; Wang, C.Q.; Gu, J. miR-146a attenuates apoptosis and modulates autophagy by targeting TAF9b/P53 pathway in doxorubicin-induced cardiotoxicity. Cell Death Dis. 2019, 10, 668. [CrossRef] [PubMed]

95. Aziz, M.M.; Abd El Fattah, M.A.; Ahmed, K.A.; Sayed, H.M. Protective effects of olmesartan and 1-carnitine on doxorubicin-induced cardiotoxicity in rats. Can. J. Physiol. Pharm. 2020, 98, 183-193. [CrossRef] [PubMed]

96. Song, S.; Chu, L.; Liang, H.; Chen, J.; Liang, J.; Huang, Z.; Zhang, B.; Chen, X. Protective Effects of Dioscin Against Doxorubicin-Induced Hepatotoxicity Via Regulation of Sirt1/FOXO1/NF-kb Signal. Front. Pharm. 2019, 10, 1030. [CrossRef] [PubMed]

97. Wali, A.F.; Rashid, S.; Rashid, S.M.; Ansari, M.A.; Khan, M.R.; Haq, N.; Alhareth, D.Y.; Ahmad, A.; Rehman, M.U. Naringenin Regulates Doxorubicin-Induced Liver Dysfunction: Impact on Oxidative Stress and Inflammation. Plants 2020, 9, 550. [CrossRef]

98. Ibrahim, K.M.; Mantawy, E.M.; Elanany, M.M.; Abdelgawad, H.S.; Khalifa, N.M.; Hussien, R.H.; El-Agroudy, N.N.; El-Demerdash, E. Protection from doxorubicin-induced nephrotoxicity by clindamycin: Novel antioxidant, anti-inflammatory and anti-apoptotic roles. Naunyn Schmiedebergs Arch. Pharm. 2020, 393, 739-748. [CrossRef]

99. Rafiee, Z.; Moaiedi, M.Z.; Gorji, A.V.; Mansouri, E. P-Coumaric Acid Mitigates Doxorubicin-Induced Nephrotoxicity Through Suppression of Oxidative Stress, Inflammation and Apoptosis. Arch. Med. Res. 2020, 51, 32-40. [CrossRef]

100. Sikandar, A.; Farhat, K.; Afzal, A.; Ajmal, K.; Laeeq, M.; Khokhar, A. Protective Effects of Trimetazidine Against Doxorubicin-Induced Cardiotoxicity And Hepatotoxicity In Mice. J. Ayub Med. Coll Abbottabad 2020, 32, 304-309.

101. Yu, X.; Ruan, Y.; Huang, X.; Dou, L.; Lan, M.; Cui, J.; Chen, B.; Gong, H.; Wang, Q.; Yan, M.; et al. Dexrazoxane ameliorates doxorubicin-induced cardiotoxicity by inhibiting both apoptosis and necroptosis in cardiomyocytes. Biochem. Biophys. Res. Commun. 2020, 523, 140-146. [CrossRef]

102. Khames, A.; Khalaf, M.M.; Gad, A.M.; Abd El-Raouf, O.M.; Kandeil, M.A. Nicorandil combats doxorubicin-induced nephrotoxicity via amendment of TLR4/P38 MAPK/NFK-B signaling pathway. Chem. Biol. Interact. 2019, 311, 108777. [CrossRef] [PubMed]

103. Maris, J.M. Recent advances in neuroblastoma. N. Engl. J. Med. 2010, 362, 2202-2211. [CrossRef] [PubMed] 
104. Brodeur, G.M. Neuroblastoma: Biological insights into a clinical enigma. Nat. Rev. Cancer 2003, 3, $203-216$. [CrossRef] [PubMed]

105. Sohara, Y.; Shimada, H.; DeClerck, Y.A. Mechanisms of bone invasion and metastasis in human neuroblastoma. Cancer Lett. 2005, 228, 203-209. [CrossRef] [PubMed]

106. Ara, T.; DeClerck, Y.A. Mechanisms of invasion and metastasis in human neuroblastoma. Cancer Metastasis Rev. 2006, 25, 645-657. [CrossRef]

107. Namkaew, J.; Jaroonwitchawan, T.; Rujanapun, N.; Saelee, J.; Noisa, P. Combined effects of curcumin and doxorubicin on cell death and cell migration of SH-SY5Y human neuroblastoma cells. Vitr. Cell Dev. Biol. Anim. 2018, 54, 629-639. [CrossRef]

108. Firouzi Amoodizaj, F.; Baghaeifar, S.; Taheri, E.; Farhoudi Sefidan Jadid, M.; Safi, M.; Seyyed Sani, N.; Hajazimian, S.; Isazadeh, A.; Shanehbandi, D. Enhanced anticancer potency of doxorubicin in combination with curcumin in gastric adenocarcinoma. J. Biochem. Mol. Toxicol. 2020, 34, e22486. [CrossRef]

109. Sadzuka, Y.; Nagamine, M.; Toyooka, T.; Ibuki, Y.; Sonobe, T. Beneficial effects of curcumin on antitumor activity and adverse reactions of doxorubicin. Int. J. Pharm. 2012, 432, 42-49. [CrossRef]

110. Viaud, S.; Saccheri, F.; Mignot, G.; Yamazaki, T.; Daillère, R.; Hannani, D.; Enot, D.P.; Pfirschke, C.; Engblom, C.; Pittet, M.J. The intestinal microbiota modulates the anticancer immune effects of cyclophosphamide. Science 2013, 342, 971-976. [CrossRef]

111. Margalit, O.; Simon, A.J.; Yakubov, E.; Puca, R.; Yosepovich, A.; Avivi, C.; Jacob-Hirsch, J.; Gelernter, I.; Harmelin, A.; Barshack, I. Zinc supplementation augments in vivo antitumor effect of chemotherapy by restoring p53 function. Int. J. Cancer 2012, 131, E562-E568. [CrossRef]

112. Fang, A.P.; Chen, P.Y.; Wang, X.Y.; Liu, Z.Y.; Zhang, D.M.; Luo, Y.; Liao, G.C.; Long, J.A.; Zhong, R.H.; Zhou, Z.G. Serum copper and zinc levels at diagnosis and hepatocellular carcinoma survival in the Guangdong Liver Cancer Cohort. Int. J. Cancer 2019, 144, 2823-2832. [CrossRef] [PubMed]

113. Wu, R.; Mei, X.; Ye, Y.; Xue, T.; Wang, J.; Sun, W.; Lin, C.; Xue, R.; Zhang, J.; Xu, D. Zn(II)-curcumin solid dispersion impairs hepatocellular carcinoma growth and enhances chemotherapy by modulating gut microbiota-mediated zinc homeostasis. Pharm. Res. 2019, 150, 104454. [CrossRef] [PubMed]

114. Zhao, L.; Niu, H.; Liu, Y.; Wang, L.; Zhang, N.; Zhang, G.; Liu, R.; Han, M. LOX inhibition downregulates MMP-2 and MMP-9 in gastric cancer tissues and cells. J. Cancer 2019, 10, 6481-6490. [CrossRef] [PubMed]

115. Chuang, C.Y.; Ho, Y.C.; Lin, C.W.; Yang, W.E.; Yu, Y.L.; Tsai, M.C.; Yang, S.F.; Su, S.C. Salvianolic acid A suppresses MMP-2 expression and restrains cancer cell invasion through ERK signaling in human nasopharyngeal carcinoma. J. Ethnopharmacol. 2020, 252, 112601. [CrossRef] [PubMed]

116. Gialeli, C.; Theocharis, A.D.; Karamanos, N.K. Roles of matrix metalloproteinases in cancer progression and their pharmacological targeting. Febs. J. 2011, 278, 16-27. [CrossRef] [PubMed]

117. Caley, M.P.; Martins, V.L.; O’Toole, E.A. Metalloproteinases and wound healing. Adv. Wound Care 2015, 4 , 225-234. [CrossRef]

118. Lee, J.H.; Mohan, C.D.; Deivasigamani, A.; Jung, Y.Y.; Rangappa, S.; Basappa, S.; Chinnathambi, A.; Alahmadi, T.A.; Alharbi, S.A.; Garg, M.; et al. Brusatol suppresses STAT3-driven metastasis by downregulating epithelial-mesenchymal transition in hepatocellular carcinoma. J. Adv. Res. 2020, 26, 83-94. [CrossRef]

119. Kalluri, R.; Weinberg, R.A. The basics of epithelial-mesenchymal transition. J. Clin. Investig. 2009, 119, 1420-1428. [CrossRef]

120. Cheng, J.-T.; Wang, L.; Wang, H.; Tang, F.-R.; Cai, W.-Q.; Sethi, G.; Xin, H.-W.; Ma, Z. Insights into biological role of LncRNAs in epithelial-mesenchymal transition. Cells 2019, 8, 1178. [CrossRef]

121. Baek, S.H.; Ko, J.H.; Lee, J.H.; Kim, C.; Lee, H.; Nam, D.; Lee, J.; Lee, S.G.; Yang, W.M.; Um, J.Y. Ginkgolic acid inhibits invasion and migration and tgf- $\beta$-induced emt of lung cancer cells through pi3k/akt/mtor inactivation. J. Cell. Physiol. 2017, 232, 346-354. [CrossRef]

122. Dai, X.; Ahn, K.S.; Wang, L.Z.; Kim, C.; Deivasigamni, A.; Arfuso, F.; Um, J.-Y.; Kumar, A.P.; Chang, Y.-C.; Kumar, D. Ascochlorin enhances the sensitivity of doxorubicin leading to the reversal of epithelial-to-mesenchymal transition in hepatocellular carcinoma. Mol. Cancer Ther. 2016, 15, 2966-2976. [CrossRef] [PubMed]

123. Kim, B.N.; Ahn, D.H.; Kang, N.; Yeo, C.D.; Kim, Y.K.; Lee, K.Y.; Kim, T.J.; Lee, S.H.; Park, M.S.; Yim, H.W.; et al. TGF- $\beta$ induced EMT and stemness characteristics are associated with epigenetic regulation in lung cancer. Sci. Rep. 2020, 10, 10597. [CrossRef] [PubMed] 
124. Marques da Fonseca, L.; Jacques da Silva, L.R.; Santos Dos Reis, J.; Rodrigues da Costa Santos, M.A.; de Sousa Chaves, V.; Monteiro da Costa, K.; Sa-Diniz, J.N.; Freire de Lima, C.G.; Morrot, A.; Nunes Franklim, T.; et al. Piperine Inhibits TGF- $\beta$ Signaling Pathways and Disrupts EMT-Related Events in Human Lung Adenocarcinoma Cells. Medicines 2020, 7, 19. [CrossRef] [PubMed]

125. Liu, Y.; Liu, Q.; Chen, S.; Liu, Y.; Huang, Y.; Chen, P.; Li, X.; Gao, G.; Xu, K.; Fan, S.; et al. APLNR is involved in ATRA-induced growth inhibition of nasopharyngeal carcinoma and may suppress EMT through PI3K-Akt-mTOR signaling. Faseb. J. 2019, 33, 11959-11972. [CrossRef] [PubMed]

126. Zhang, X.; Liu, S.; Zhu, Y. A-kinase-interacting protein 1 promotes EMT and metastasis via PI3K/Akt/IKK $\beta$ pathway in cervical cancer. Cell Biochem. Funct. 2020, 38, 782-791. [CrossRef] [PubMed]

127. Chen, W.C.; Lai, Y.A.; Lin, Y.C.; Ma, J.W.; Huang, L.F.; Yang, N.S.; Ho, C.T.; Kuo, S.C.; Way, T.D. Curcumin suppresses doxorubicin-induced epithelial-mesenchymal transition via the inhibition of TGF- $\beta$ and PI3K/AKT signaling pathways in triple-negative breast cancer cells. J. Agric. Food Chem. 2013, 61, 11817-11824. [CrossRef]

128. Ween, M.P.; Armstrong, M.A.; Oehler, M.K.; Ricciardelli, C. The role of ABC transporters in ovarian cancer progression and chemoresistance. Crit. Rev. Oncol. Hematol. 2015, 96, 220-256. [CrossRef]

129. Van der Bliek, A.M.; Baas, F.; Ten Houte de Lange, T.; Kooiman, P.M.; Van der Velde-Koerts, T.; Borst, P. The human mdr3 gene encodes a novel P-glycoprotein homologue and gives rise to alternatively spliced mRNAs in liver. Embo J. 1987, 6, 3325-3331. [CrossRef]

130. Zhang, L.; Li, Y.; Wang, Q.; Chen, Z.; Li, X.; Wu, Z.; Hu, C.; Liao, D.; Zhang, W.; Chen, Z.S. The PI3K subunits, P110 $\alpha$ and P110 $\beta$ are potential targets for overcoming P-gp and BCRP-mediated MDR in cancer. Mol. Cancer 2020, 19, 10. [CrossRef]

131. Khonkarn, R.; Daowtak, K.; Okonogi, S. Chemotherapeutic Efficacy Enhancement in P-gp-Overexpressing Cancer Cells by Flavonoid-Loaded Polymeric Micelles. Aaps Pharmscitech. 2020, 21, 121. [CrossRef]

132. Nicolas, E.; Ramus, C.; Berthier, S.; Arlotto, M.; Bouamrani, A.; Lefebvre, C.; Morel, F.; Garin, J.; Ifrah, N.; Berger, F.; et al. Expression of S100A8 in leukemic cells predicts poor survival in de novo AML patients. Leukemia 2011, 25, 57-65. [CrossRef] [PubMed]

133. Spijkers-Hagelstein, J.A.; Schneider, P.; Hulleman, E.; de Boer, J.; Williams, O.; Pieters, R.; Stam, R.W. Elevated S100A8/S100A9 expression causes glucocorticoid resistance in MLL-rearranged infant acute lymphoblastic leukemia. Leukemia 2012, 26, 1255-1265. [CrossRef] [PubMed]

134. Yang, X.Y.; Zhang, M.Y.; Zhou, Q.; Wu, S.Y.; Zhao, Y.; Gu, W.Y.; Pan, J.; Cen, J.N.; Chen, Z.X.; Guo, W.G.; et al. High expression of S100A8 gene is associated with drug resistance to etoposide and poor prognosis in acute myeloid leukemia through influencing the apoptosis pathway. Oncol. Targets 2016, 9, 4887-4899. [CrossRef]

135. Wen, C.; Fu, L.; Huang, J.; Dai, Y.; Wang, B.; Xu, G.; Wu, L.; Zhou, H. Curcumin reverses doxorubicin resistance via inhibition the efflux function of ABCB4 in doxorubicin-resistant breast cancer cells. Mol. Med. Rep. 2019, 19,5162-5168. [CrossRef]

136. Gao, M.; Liu, T.; Li, J.; Guan, Q.; Wang, H.; Yan, S.; Li, Z.; Zuo, D.; Zhang, W.; Wu, Y. YAN, a novel microtubule inhibitor, inhibits P-gp and MRP1 function and induces mitotic slippage followed by apoptosis in multidrug-resistant A549/Taxol cells. Toxicol. Vitr. 2020, 69, 104971. [CrossRef]

137. Li, H.; Krstin, S.; Wink, M. Modulation of multidrug resistant in cancer cells by EGCG, tannic acid and curcumin. Phytomedicine 2018, 50, 213-222. [CrossRef]

138. Yang, L.; Li, D.; Tang, P.; Zuo, Y. Curcumin increases the sensitivity of K562/DOX cells to doxorubicin by targeting S100 calcium-binding protein A8 and P-glycoprotein. Oncol. Lett. 2020, 19, 83-92. [CrossRef]

139. Zhao, G.; Sun, Y.; Dong, X. Zwitterionic Polymer Micelles with Dual Conjugation of Doxorubicin and Curcumin: Synergistically Enhanced Efficacy against Multidrug-Resistant Tumor Cells. Langmuir 2020, 36, 2383-2395. [CrossRef]

140. Huang, J.; Chen, Y.; Li, J.; Zhang, K.; Chen, J.; Chen, D.; Feng, B.; Song, H.; Feng, J.; Wang, R.; et al. Notch-1 Confers Chemoresistance in Lung Adenocarcinoma to Taxanes through AP-1/microRNA-451 Mediated Regulation of MDR-1. Mol. Nucleic Acids 2016, 5, e375. [CrossRef]

141. Meng, Q.; Liang, C.; Hua, J.; Zhang, B.; Liu, J.; Zhang, Y.; Wei, M.; Yu, X.; Xu, J.; Shi, S. A miR-146a-5p/TRAF6/NF-kB p65 axis regulates pancreatic cancer chemoresistance: Functional validation and clinical significance. Theranostics 2020, 10, 3967-3979. [CrossRef] 
142. Dhandapani, K.M.; Mahesh, V.B.; Brann, D.W. Curcumin suppresses growth and chemoresistance of human glioblastoma cells via AP-1 and NFkappaB transcription factors. J. Neurochem. 2007, 102, 522-538. [CrossRef] [PubMed]

143. Meng, S.; Tripathy, D.; Shete, S.; Ashfaq, R.; Haley, B.; Perkins, S.; Beitsch, P.; Khan, A.; Euhus, D.; Osborne, C.; et al. HER-2 gene amplification can be acquired as breast cancer progresses. Proc. Natl. Acad Sci. USA 2004, 101, 9393-9398. [CrossRef] [PubMed]

144. Jin, L.; Ma, X.M.; Wang, T.T.; Yang, Y.; Zhang, N.; Zeng, N.; Bai, Z.G.; Yin, J.; Zhang, J.; Ding, G.Q.; et al. Psoralen Suppresses Cisplatin-Mediated Resistance and Induces Apoptosis of Gastric Adenocarcinoma by Disruption of the miR196a-HOXB7-HER2 Axis. Cancer Manag. Res. 2020, 12, 2803-2827. [CrossRef] [PubMed]

145. Meiyanto, E.; Putri, D.D.; Susidarti, R.A.; Murwanti, R.; Sardjiman, R.A.; Fitriasari, A.; Husnaa, U.; Purnomo, H.; Kawaichi, M. Curcumin and its analogues (PGV-0 and PGV-1) enhance sensitivity of resistant MCF-7 cells to doxorubicin through inhibition of HER2 and NF-кB activation. Asian Pac. J. Cancer Prev. 2014, 15, 179-184. [CrossRef]

146. Klippstein, R.; Bansal, S.S.; Al-Jamal, K.T. Doxorubicin enhances curcumin's cytotoxicity in human prostate cancer cells in vitro by enhancing its cellular uptake. Int. J. Pharm. 2016, 514, 169-175. [CrossRef]

147. Notarbartolo, M.; Poma, P.; Perri, D.; Dusonchet, L.; Cervello, M.; D'Alessandro, N. Antitumor effects of curcumin, alone or in combination with cisplatin or doxorubicin, on human hepatic cancer cells. Analysis of their possible relationship to changes in NF- $\mathrm{kB}$ activation levels and in IAP gene expression. Cancer Lett. 2005, 224, 53-65. [CrossRef]

148. El-Far, A.H.; Darwish, N.H.E.; Mousa, S.A. Senescent Colon and Breast Cancer Cells Induced by Doxorubicin Exhibit Enhanced Sensitivity to Curcumin, Caffeine, and Thymoquinone. Integr. Cancer 2020, 19. [CrossRef]

149. Renu, K.; Abilash, V.G.; Tirupathi Pichiah, P.B.; Arunachalam, S. Molecular mechanism of doxorubicin-induced cardiomyopathy-An update. Eur. J. Pharmacol. 2018, 818, 241-253. [CrossRef]

150. Alexander, J.L.; Wilson, I.D.; Teare, J.; Marchesi, J.R.; Nicholson, J.K.; Kinross, J.M. Gut microbiota modulation of chemotherapy efficacy and toxicity. Nat. Rev. Gastroenterol. Hepatol. 2017, 14, 356-365. [CrossRef]

151. Wallace, B.D.; Wang, H.; Lane, K.T.; Scott, J.E.; Orans, J.; Koo, J.S.; Venkatesh, M.; Jobin, C.; Yeh, L.-A.; Mani, S. Alleviating cancer drug toxicity by inhibiting a bacterial enzyme. Science 2010, 330, 831-835. [CrossRef]

152. Wu, C.-H.; Ko, J.-L.; Liao, J.-M.; Huang, S.-S.; Lin, M.-Y.; Lee, L.-H.; Chang, L.-Y.; Ou, C.-C. D-methionine alleviates cisplatin-induced mucositis by restoring the gut microbiota structure and improving intestinal inflammation. Ther. Adv. Med. Oncol. 2019, 11. [CrossRef] [PubMed]

153. Montassier, E.; Gastinne, T.; Vangay, P.; Al-Ghalith, G.; Bruley des Varannes, S.; Massart, S.; Moreau, P.; Potel, G.; de La Cochetiere, M.; Batard, E. Chemotherapy-driven dysbiosis in the intestinal microbiome. Aliment. Pharmacol. Ther. 2015, 42,515-528. [CrossRef] [PubMed]

154. Wang, L.; Chen, Q.; Qi, H.; Wang, C.; Wang, C.; Zhang, J.; Dong, L. Doxorubicin-induced systemic inflammation is driven by upregulation of toll-like receptor TLR4 and endotoxin leakage. Cancer Res. 2016, 76, 6631-6642. [CrossRef] [PubMed]

155. Carr, J.S.; King, S.; Dekaney, C.M. Depletion of enteric bacteria diminishes leukocyte infiltration following doxorubicin-induced small intestinal damage in mice. PLoS ONE 2017, 12, e0173429. [CrossRef]

156. Wu, R.; Mei, X.; Wang, J.; Sun, W.; Xue, T.; Lin, C.; Xu, D. Zn(ii)-Curcumin supplementation alleviates gut dysbiosis and zinc dyshomeostasis during doxorubicin-induced cardiotoxicity in rats. Food Funct. 2019, 10, 5587-5604. [CrossRef]

157. Mantawy, E.M.; El-Bakly, W.M.; Esmat, A.; Badr, A.M.; El-Demerdash, E. Chrysin alleviates acute doxorubicin cardiotoxicity in rats via suppression of oxidative stress, inflammation and apoptosis. Eur. J. Pharmacol. 2014, 728, 107-118. [CrossRef]

158. Benzer, F.; Kandemir, F.M.; Ozkaraca, M.; Kucukler, S.; Caglayan, C. Curcumin ameliorates doxorubicin-induced cardiotoxicity by abrogation of inflammation, apoptosis, oxidative DNA damage, and protein oxidation in rats. J. Biochem. Mol. Toxicol. 2018, 32, e22030. [CrossRef]

159. Hou, N.; Mai, Y.; Qiu, X.; Yuan, W.; Li, Y.; Luo, C.; Liu, Y.; Zhang, G.; Zhao, G.; Luo, J.D. Carvacrol Attenuates Diabetic Cardiomyopathy by Modulating the PI3K/AKT/GLUT4 Pathway in Diabetic Mice. Front. Pharm. 2019, 10, 998. [CrossRef] 
160. Jamhiri, M.; Safi Dahaj, F.; Astani, A.; Hejazian, S.H.; Hafizibarjin, Z.; Ghobadi, M.; Moradi, A.; Khoradmehr, A.; Safari, F. Carvacrol Ameliorates Pathological Cardiac Hypertrophy in Both In-vivo and In-vitro Models. Iran J. Pharm. Res. 2019, 18, 1380-1394. [CrossRef]

161. Jafarinezhad, Z.; Rafati, A.; Ketabchi, F.; Noorafshan, A.; Karbalay-Doust, S. Cardioprotective effects of curcumin and carvacrol in doxorubicin-treated rats: Stereological study. Food Sci. Nutr. 2019, 7, 3581-3588. [CrossRef]

162. Kwong, J.Q.; Davis, J.; Baines, C.P.; Sargent, M.A.; Karch, J.; Wang, X.; Huang, T.; Molkentin, J.D. Genetic deletion of the mitochondrial phosphate carrier desensitizes the mitochondrial permeability transition pore and causes cardiomyopathy. Cell Death Differ. 2014, 21, 1209-1217. [CrossRef] [PubMed]

163. Alcalá, S.; Klee, M.; Fernández, J.; Fleischer, A.; Pimentel-Muiños, F.X. A high-throughput screening for mammalian cell death effectors identifies the mitochondrial phosphate carrier as a regulator of cytochrome $\mathrm{C}$ release. Oncogene 2008, 27, 44-54. [CrossRef] [PubMed]

164. Junkun, L.; Erfu, C.; Tony, H.; Xin, L.; Sudeep, K.C.; Mingliang, Z.; Yanqin, W.; XiangQian, Q. Curcumin Downregulates Phosphate Carrier and Protects against Doxorubicin Induced Cardiomyocyte Apoptosis. Biomed. Res. Int. 2016, 2016, 1980763. [CrossRef] [PubMed]

165. He, H.; Luo, Y.; Qiao, Y.; Zhang, Z.; Yin, D.; Yao, J.; You, J.; He, M. Curcumin attenuates doxorubicin-induced cardiotoxicity via suppressing oxidative stress and preventing mitochondrial dysfunction mediated by

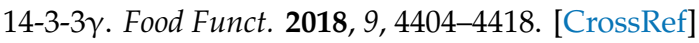

166. Yadav, Y.C.; Pattnaik, S.; Swain, K. Curcumin loaded mesoporous silica nanoparticles: Assessment of bioavailability and cardioprotective effect. Drug. Dev. Ind. Pharm. 2019, 45, 1889-1895. [CrossRef]

167. Mohammed, H.S.; Hosny, E.N.; Khadrawy, Y.A.; Magdy, M.; Attia, Y.S.; Sayed, O.A.; AbdElaal, M. Protective effect of curcumin nanoparticles against cardiotoxicity induced by doxorubicin in rat. Biochim. Biophys. Acta Mol. Basis Dis. 2020, 1866, 165665. [CrossRef]

168. Jain, A.; Rani, V. Mode of treatment governs curcumin response on doxorubicin-induced toxicity in cardiomyoblasts. Mol. Cell. Biochem. 2018, 442, 81-96. [CrossRef]

169. Aksu, E.H.; Kandemir, F.M.; Yıldırım, S.; Küçükler, S.; Dörtbudak, M.B.; Çağlayan, C.; Benzer, F. Palliative effect of curcumin on doxorubicin-induced testicular damage in male rats. J. Biochem. Mol. Toxicol. 2019, 33, e22384. [CrossRef]

170. Saad, S.Y.; Najjar, T.A.; Al-Rikabi, A.C. The preventive role of deferoxamine against acute doxorubicin-induced cardiac, renal and hepatic toxicity in rats. Pharmacol. Res. 2001, 43, 211-218. [CrossRef]

171. Rashid, S.; Ali, N.; Nafees, S.; Ahmad, S.T.; Arjumand, W.; Hasan, S.K.; Sultana, S. Alleviation of doxorubicin-induced nephrotoxicity and hepatotoxicity by chrysin in Wistar rats. Toxicol. Mech. Methods 2013, 23, 337-345. [CrossRef]

172. Benzer, F.; Kandemir, F.M.; Kucukler, S.; Comakl1, S.; Caglayan, C. Chemoprotective effects of curcumin on doxorubicin-induced nephrotoxicity in wistar rats: By modulating inflammatory cytokines, apoptosis, oxidative stress and oxidative DNA damage. Arch. Physiol. Biochem. 2018, 124, 448-457. [CrossRef] [PubMed]

173. Noone, D.G.; Iijima, K.; Parekh, R. Idiopathic nephrotic syndrome in children. Lancet 2018, 392, 61-74. [CrossRef]

174. Fan, H.Y.; Wang, X.K.; Li, X.; Ji, K.; Du, S.H.; Liu, Y.; Kong, L.L.; Xu, J.C.; Yang, G.Q.; Chen, D.Q.; et al. Curcumin, as a pleiotropic agent, improves doxorubicin-induced nephrotic syndrome in rats. J. Ethnopharmacol. 2020, 250, 112502. [CrossRef] [PubMed]

175. Li, C.L.; Liu, X.H.; Qiao, Y.; Ning, L.N.; Li, W.J.; Sun, Y.S.; Liu, D.S.; Gao, W.; Ma, C.M. Allicin alleviates inflammation of diabetic macroangiopathy via the Nrf2 and NF-kB pathway. Eur. J. Pharm. 2020, 876, 173052. [CrossRef]

176. Hannan, M.A.; Dash, R.; Sohag, A.A.M.; Haque, M.N.; Moon, I.S. Neuroprotection Against Oxidative Stress: Phytochemicals Targeting TrkB Signaling and the Nrf2-ARE Antioxidant System. Front. Mol. Neurosci. 2020, 13, 116. [CrossRef]

177. Ungvari, Z.; Tarantini, S.; Nyúl-Tóth, Á.; Kiss, T.; Yabluchanskiy, A.; Csipo, T.; Balasubramanian, P.; Lipecz, A.; Benyo, Z.; Csiszar, A. Nrf2 dysfunction and impaired cellular resilience to oxidative stressors in the aged vasculature: From increased cellular senescence to the pathogenesis of age-related vascular diseases. Geroscience 2019, 41, 727-738. [CrossRef]

178. Imbaby, S.; Ewais, M.; Essawy, S.; Farag, N. Cardioprotective effects of curcumin and nebivolol against doxorubicin-induced cardiac toxicity in rats. Hum. Exp. Toxicol. 2014, 33, 800-813. [CrossRef] 
179. Wang, L.; Song, Y.; Parikh, A.; Joyce, P.; Chung, R.; Liu, L.; Afinjuomo, F.; Hayball, J.D.; Petrovsky, N.; Barclay, T.G.; et al. Doxorubicin-Loaded Delta Inulin Conjugates for Controlled and Targeted Drug Delivery: Development, Characterization, and In Vitro Evaluation. Pharmaceutics 2019, 11. [CrossRef]

180. Li, H.; Zhang, N.; Hao, Y.; Wang, Y.; Jia, S.; Zhang, H. Enhancement of curcumin antitumor efficacy and further photothermal ablation of tumor growth by single-walled carbon nanotubes delivery system in vivo. Drug Deliv. 2019, 26, 1017-1026. [CrossRef]

181. Mohammadinejad, R.; Dehshahri, A.; Madamsetty, V.S.; Zahmatkeshan, M.; Tavakol, S.; Makvandi, P.; Khorsandi, D.; Pardakhty, A.; Ashrafizadeh, M.; Afshar, E.G. In vivo gene delivery mediated by non-viral vectors for cancer therapy. J. Control. Release 2020, 325, 249-275. [CrossRef]

182. Vandita, K.; Shashi, B.; Santosh, K.G.; Pal, K.I. Enhanced apoptotic effect of curcumin loaded solid lipid nanoparticles. Mol. Pharm. 2012, 9, 3411-3421. [CrossRef] [PubMed]

183. Puglia, C.; Frasca, G.; Musumeci, T.; Rizza, L.; Puglisi, G.; Bonina, F.; Chiechio, S. Curcumin loaded NLC induces histone hypoacetylation in the CNS after intraperitoneal administration in mice. Eur. J. Pharm. Biopharm. 2012, 81, 288-293. [CrossRef] [PubMed]

184. Kang, K.W.; Chun, M.K.; Kim, O.; Subedi, R.K.; Ahn, S.G.; Yoon, J.H.; Choi, H.K. Doxorubicin-loaded solid lipid nanoparticles to overcome multidrug resistance in cancer therapy. Nanomedicine 2010, 6, 210-213. [CrossRef] [PubMed]

185. Wong, H.L.; Rauth, A.M.; Bendayan, R.; Manias, J.L.; Ramaswamy, M.; Liu, Z.; Erhan, S.Z.; Wu, X.Y. A new polymer-lipid hybrid nanoparticle system increases cytotoxicity of doxorubicin against multidrug-resistant human breast cancer cells. Pharm. Res. 2006, 23, 1574-1585. [CrossRef] [PubMed]

186. Zhao, X.; Chen, Q.; Liu, W.; Li, Y.; Tang, H.; Liu, X.; Yang, X. Codelivery of doxorubicin and curcumin with lipid nanoparticles results in improved efficacy of chemotherapy in liver cancer. Int. J. Nanomed. 2015, 10, 257-270. [CrossRef]

187. Zhao, X.; Chen, Q.; Li, Y.; Tang, H.; Liu, W.; Yang, X. Doxorubicin and curcumin co-delivery by lipid nanoparticles for enhanced treatment of diethylnitrosamine-induced hepatocellular carcinoma in mice. Eur. J. Pharm. Biopharm. 2015, 93, 27-36. [CrossRef]

188. Dong, H.; Hu, J.; Wang, L.; Qi, M.; Lu, N.; Tan, X.; Yang, M.; Bai, X.; Zhan, X.; Han, B. SOX4 is activated by C-MYC in prostate cancer. Med. Oncol. 2019, 36, 92. [CrossRef]

189. Cai, H.; Gong, L.; Liu, J.; Zhou, Q.; Zheng, Z. Diosgenin inhibits tumor angiogenesis through regulating GRP78-mediated HIF-1 $\alpha$ and VEGF/VEGFR signaling pathways. Pharmazie 2019, 74, 680-684. [CrossRef]

190. Xiong, X.-B.; Falamarzian, A.; Garg, S.M.; Lavasanifar, A. Engineering of amphiphilic block copolymers for polymeric micellar drug and gene delivery. J. Control. Release 2011, 155, 248-261.

191. Li, P.-Y.; Lai, P.-S.; Hung, W.-C.; Syu, W.-J. Poly (L-lactide)-vitamin E TPGS nanoparticles enhanced the cytotoxicity of doxorubicin in drug-resistant MCF-7 breast cancer cells. Biomacromolecules 2010, 11, 2576-2582.

192. Vandenplas, Y.; Bacarea, A.; Marusteri, M.; Bacarea, V.; Constantin, M.; Manolache, M. Efficacy and safety of APT198K for the treatment of infantile colic: A pilot study. J. Comp. Eff. Res. 2017, 6, 137-144. [CrossRef] [PubMed]

193. Zhang, D.; Xu, Q.; Wang, N.; Yang, Y.; Liu, J.; Yu, G.; Yang, X.; Xu, H.; Wang, H. A complex micellar system co-delivering curcumin with doxorubicin against cardiotoxicity and tumor growth. Int. J. Nanomed. 2018, 13, 4549-4561. [CrossRef] [PubMed]

194. Karavasili, C.; Andreadis, D.A.; Katsamenis, O.L.; Panteris, E.; Anastasiadou, P.; Kakazanis, Z.; Zoumpourlis, V.; Markopoulou, C.K.; Koutsopoulos, S.; Vizirianakis, I.S. Synergistic antitumor potency of a self-assembling peptide hydrogel for the local co-delivery of doxorubicin and curcumin in the treatment of head and neck cancer. Mol. Pharm. 2019, 16, 2326-2341. [CrossRef] [PubMed]

195. Mueckler, M.; Thorens, B. The SLC2 (GLUT) family of membrane transporters. Mol. Asp. Med. 2013, 34, 121-138. [CrossRef]

196. Szablewski, L. Expression of glucose transporters in cancers. Biochim. Biophys. Acta Rev. Cancer 2013, 1835, 164-169. [CrossRef]

197. Warburg, O. On the origin of cancer cells. Science 1956, 123, 309-314. [CrossRef]

198. Yeh, W.-L.; Lin, C.-J.; Fu, W.-M. Enhancement of glucose transporter expression of brain endothelial cells by vascular endothelial growth factor derived from glioma exposed to hypoxia. Mol. Pharmacol. 2008, 73, 170-177. [CrossRef] 
199. Boado, R.J.; Black, K.L.; Pardridge, W.M. Gene expression of GLUT3 and GLUT1 glucose transporters in human brain tumors. Mol. Brain Res. 1994, 27, 51-57. [CrossRef]

200. Sarisozen, C.; Dhokai, S.; Tsikudo, E.G.; Luther, E.; Rachman, I.M.; Torchilin, V.P. Nanomedicine based curcumin and doxorubicin combination treatment of glioblastoma with scFv-targeted micelles: In vitro evaluation on 2D and 3D tumor models. Eur. J. Pharm. Biopharm. 2016, 108, 54-67. [CrossRef]

201. Huang, J.; Shen, F.; Huang, H.; Ling, C.; Zhang, G. Th1high in tumor microenvironment is an indicator of poor prognosis for patients with NSCLC. Oncotarget 2017, 8, 13116-13125. [CrossRef]

202. Thakkar, S.; Sharma, D.; Kalia, K.; Tekade, R.K. Tumor microenvironment targeted nanotherapeutics for cancer therapy and diagnosis: A review. Acta Biomater. 2020, 101, 43-68. [CrossRef] [PubMed]

203. Sesarman, A.; Tefas, L.; Sylvester, B.; Licarete, E.; Rauca, V.; Luput, L.; Patras, L.; Porav, S.; Banciu, M.; Porfire, A. Co-delivery of curcumin and doxorubicin in PEGylated liposomes favored the antineoplastic C26 murine colon carcinoma microenvironment. Drug Deliv. Transl. Res. 2019, 9, 260-272. [CrossRef] [PubMed]

204. Bisht, S.; Maitra, A. Dextran-doxorubicin/chitosan nanoparticles for solid tumor therapy. Wiley Interdiscip. Rev. Nanomed. Nanobiotechnol. 2009, 1, 415-425. [CrossRef] [PubMed]

205. Matsumura, Y.; Kataoka, K. Preclinical and clinical studies of anticancer agent-incorporating polymer micelles. Cancer Sci. 2009, 100, 572-579. [CrossRef]

206. Gupta, M.; Agrawal, G.P.; Vyas, S.P. Polymeric nanomedicines as a promising vehicle for solid tumor therapy and targeting. Curr. Mol. Med. 2013, 13, 179-204. [CrossRef]

207. Maeda, H.; Bharate, G.Y.; Daruwalla, J. Polymeric drugs for efficient tumor-targeted drug delivery based on EPR-effect. Eur. J. Pharm. Biopharm. 2009, 71, 409-419. [CrossRef]

208. Deng, M.; Nair, L.S.; Nukavarapu, S.P.; Kumbar, S.G.; Jiang, T.; Krogman, N.R.; Singh, A.; Allcock, H.R.; Laurencin, C.T. Miscibility and in vitro osteocompatibility of biodegradable blends of poly[(ethyl alanato)(p-phenyl phenoxy)phosphazene] and poly(lactic acid-glycolic acid). Biomaterials 2008, 29, 337-349. [CrossRef]

209. Guo, W.; Song, Y.; Song, W.; Liu, Y.; Liu, Z.; Zhang, D.; Tang, Z.; Bai, O. Co-delivery of Doxorubicin and Curcumin with Polypeptide Nanocarrier for Synergistic Lymphoma Therapy. Sci. Rep. 2020, 10, 7832. [CrossRef]

210. He, L.; Qing, F.; Li, M.; Lan, D. Paclitaxel/IR1061-Co-Loaded Protein Nanoparticle for Tumor-Targeted and pH/NIR-II-Triggered Synergistic Photothermal-Chemotherapy. Int. J. Nanomed. 2020, 15, 2337-2349. [CrossRef]

211. Cai, X.; Yang, Q.; Weng, Q.; Wang, S. pH sensitive doxorubicin-loaded nanoparticle based on Radix pseudostellariae protein-polysaccharide conjugate and its improvement on HepG2 cellular uptake of doxorubicin. Food Chem. Toxicol. 2020, 136, 111099. [CrossRef]

212. Abdalla, M.O.; Karna, P.; Sajja,H.K.; Mao, H.; Yates, C.; Turner, T.; Aneja, R. Enhanced noscapine delivery using uPAR-targeted optical-MR imaging trackable nanoparticles for prostate cancer therapy. J. Control. Release 2011, 149, 314-322. [CrossRef] [PubMed]

213. Persson, M.; Juhl, K.; Rasmussen, P.; Brandt-Larsen, M.; Madsen, J.; Ploug, M.; Kjær, A. uPAR targeted radionuclide therapy with $177 \mathrm{Lu}-\mathrm{DOTA}-\mathrm{AE} 105$ inhibits dissemination of metastatic prostate cancer. Mol. Pharm. 2014, 11, 2796-2806. [CrossRef] [PubMed]

214. Li, R.; Zheng, K.; Hu, P.; Chen, Z.; Zhou, S.; Chen, J.; Yuan, C.; Chen, S.; Zheng, W.; Ma, E. A novel tumor targeting drug carrier for optical imaging and therapy. Theranostics 2014, 4, 642. [CrossRef] [PubMed]

215. Miao, J.-T.; Ge, M.; Peng, S.; Zhong, J.; Li, Y.; Weng, Z.; Wu, L.; Zheng, L. Dynamic imine bonds based shape memory polymers with permanent shape reconfigurability for $4 \mathrm{D}$ printing. Acs Appl. Mater. Interfaces 2019, 11, 40642-40651. [CrossRef] [PubMed]

216. Kratz, F.; Müller, I.A.; Ryppa, C.; Warnecke, A. Prodrug strategies in anticancer chemotherapy. Chem. Med. Chem. 2008, 3, 20-53. [CrossRef] [PubMed]

217. Khandare, J.J.; Chandna, P.; Wang, Y.; Pozharov, V.P.; Minko, T. Novel polymeric prodrug with multivalent components for cancer therapy. J. Pharm. Exp. 2006, 317, 929-937. [CrossRef]

218. Zhang, Y.; Yang, C.; Wang, W.; Liu, J.; Liu, Q.; Huang, F.; Chu, L.; Gao, H.; Li, C.; Kong, D.; et al. Co-delivery of doxorubicin and curcumin by $\mathrm{pH}$-sensitive prodrug nanoparticle for combination therapy of cancer. Sci. Rep. 2016, 6, 21225. [CrossRef]

219. Gu, Y.; Li, J.; Li, Y.; Song, L.; Li, D.; Peng, L.; Wan, Y.; Hua, S. Nanomicelles loaded with doxorubicin and curcumin for alleviating multidrug resistance in lung cancer. Int. J. Nanomed. 2016, 11, 5757-5770. [CrossRef] 
220. Pramanik, D.; Majeti, B.K.; Mondal, G.; Karmali, P.P.; Sistla, R.; Ramprasad, O.G.; Srinivas, G.; Pande, G.; Chaudhuri, A. Lipopeptide with a RGDK tetrapeptide sequence can selectively target genes to proangiogenic $\alpha 5 \beta 1$ integrin receptor and mouse tumor vasculature. J. Med. Chem. 2008, 51, 7298-7302. [CrossRef]

221. Barui, S.; Saha, S.; Mondal, G.; Haseena, S.; Chaudhuri, A. Simultaneous delivery of doxorubicin and curcumin encapsulated in liposomes of pegylated RGDK-lipopeptide to tumor vasculature. Biomaterials 2014, 35, 1643-1656. [CrossRef]

222. Reddy, K.L.; Sharma, P.K.; Singh, A.; Kumar, A.; Shankar, K.R.; Singh, Y.; Garg, N.; Krishnan, V. Amine-functionalized, porous silica-coated $\mathrm{NaYF}(4): \mathrm{Yb} / \mathrm{Er}$ upconversion nanophosphors for efficient delivery of doxorubicin and curcumin. Mater. Sci. Eng. C Mater. Biol. Appl. 2019, 96, 86-95. [CrossRef] [PubMed]

223. Fawzy, N.G.; Panda, S.S.; Fayad, W.; El-Manawaty, M.A.; Srour, A.M.; Girgis, A.S. Novel Curcumin Inspired Antineoplastic 1-Sulfonyl-4-Piperidones: Design, Synthesis and Molecular Modeling Studies. Anticancer Agents Med. Chem. 2019, 19, 1069-1078. [CrossRef] [PubMed]

224. Zhang, J.; Li, J.; Shi, Z.; Yang, Y.; Xie, X.; Lee, S.M.; Wang, Y.; Leong, K.W.; Chen, M. pH-sensitive polymeric nanoparticles for co-delivery of doxorubicin and curcumin to treat cancer via enhanced pro-apoptotic and anti-angiogenic activities. Acta Biomater. 2017, 58, 349-364. [CrossRef] [PubMed]

225. Peng, J.; Fumoto, S.; Miyamoto, H.; Chen, Y.; Kuroda, N.; Nishida, K. One-step formation of lipid-polyacrylic acid-calcium carbonate nanoparticles for co-delivery of doxorubicin and curcumin. J. Drug Target. 2017, 25, 704-714. [CrossRef] [PubMed]

226. Tefas, L.R.; Sylvester, B.; Tomuta, I.; Sesarman, A.; Licarete, E.; Banciu, M.; Porfire, A. Development of antiproliferative long-circulating liposomes co-encapsulating doxorubicin and curcumin, through the use of a quality-by-design approach. Drug Des. Dev. Ther. 2017, 11, 1605-1621. [CrossRef] [PubMed]

227. Yuan, J.D.; ZhuGe, D.L.; Tong, M.Q.; Lin, M.T.; Xu, X.F.; Tang, X.; Zhao, Y.Z.; Xu, H.L. pH-sensitive polymeric nanoparticles of mPEG-PLGA-PGlu with hybrid core for simultaneous encapsulation of curcumin and doxorubicin to kill the heterogeneous tumour cells in breast cancer. Artif. Cells Nanomed. Biotechnol. 2018, 46, 302-313. [CrossRef]

228. Yousef, S.; Alsaab, H.O.; Sau, S.; Iyer, A.K. Development of asialoglycoprotein receptor directed nanoparticles for selective delivery of curcumin derivative to hepatocellular carcinoma. Heliyon 2018, 4, e01071. [CrossRef]

229. Zhou, Y.; Zhou, C.; Zou, Y.; Jin, Y.; Han, S.; Liu, Q.; Hu, X.; Wang, L.; Ma, Y.; Liu, Y. Multi pH-sensitive polymer-drug conjugate mixed micelles for efficient co-delivery of doxorubicin and curcumin to synergistically suppress tumor metastasis. Biomater. Sci. 2020, 8, 5029-5046. [CrossRef]

230. Hong, W.; Shi, H.; Qiao, M.; Zhang, Z.; Yang, W.; Dong, L.; Xie, F.; Zhao, C.; Kang, L. pH-sensitive micelles for the intracellular co-delivery of curcumin and Pluronic L61 unimers for synergistic reversal effect of multidrug resistance. Sci. Rep. 2017, 7, 42465. [CrossRef]

231. Zhang, G.; Li, X.; Liao, Q.; Liu, Y.; Xi, K.; Huang, W.; Jia, X. Water-dispersible PEG-curcumin/aminefunctionalized covalent organic framework nanocomposites as smart carriers for in vivo drug delivery. Nat. Commun. 2018, 9, 2785. [CrossRef]

232. Rastegar, R.; Akbari Javar, H.; Khoobi, M.; Dehghan Kelishadi, P.; Hossein Yousefi, G.; Doosti, M.; Hossien Ghahremani, M.; Shariftabrizi, A.; Imanparast, F.; Gholibeglu, E.; et al. Evaluation of a novel biocompatible magnetic nanomedicine based on beta-cyclodextrin, loaded doxorubicin-curcumin for overcoming chemoresistance in breast cancer. Artif. Cells Nanomed. Biotechnol. 2018, 46, 207-216. [CrossRef] [PubMed]

233. Lin, J.T.; Ye, Q.B.; Yang, Q.J.; Wang, G.H. Hierarchical bioresponsive nanocarriers for codelivery of curcumin and doxorubicin. Colloids Surf. B Biointerfaces 2019, 180, 93-101. [CrossRef] [PubMed]

234. Sesarman, A.; Muntean, D.; Abrudan, B.; Tefas, L.; Sylvester, B.; Licarete, E.; Rauca, V.; Luput, L.; Patras, L.; Banciu, M.; et al. Improved pharmacokinetics and reduced side effects of doxorubicin therapy by liposomal co-encapsulation with curcumin. J. Liposome Res. 2019, 1-10. [CrossRef] [PubMed]

235. Yang, M.; Yu, L.; Guo, R.; Dong, A.; Lin, C.; Zhang, J. A Modular Coassembly Approach to All-In-One Multifunctional Nanoplatform for Synergistic Codelivery of Doxorubicin and Curcumin. Nanomaterial 2018, 8, 167. [CrossRef]

236. Rejinold, N.S.; Yoo, J.; Jon, S.; Kim, Y.C. Curcumin as a Novel Nanocarrier System for Doxorubicin Delivery to MDR Cancer Cells: In vitro and in vivo Evaluation. ACS Appl. Mater. Interfaces 2018, 10, 28458-28470. [CrossRef] 
237. Yan, T.; Li, D.; Li, J.; Cheng, F.; Cheng, J.; Huang, Y.; He, J. Effective co-delivery of doxorubicin and curcumin using a glycyrrhetinic acid-modified chitosan-cystamine-poly( $\varepsilon$-caprolactone) copolymer micelle for combination cancer chemotherapy. Colloids Surf. B Biointerfaces 2016, 145, 526-538. [CrossRef]

238. Sabzi, A.; Rahmani, A.; Edalati, M.; Kahroba, H.; Dadpour, M.R.; Salehi, R.; Zarebkohan, A. Targeted co-delivery of curcumin and doxorubicin by citric acid functionalized Poly ( $\varepsilon$-caprolactone) based micelle in MDA-MB-231 cell. Colloids Surf. B Biointerfaces 2020, 194, 111225. [CrossRef]

239. Kumari, M.; Purohit, M.P.; Patnaik, S.; Shukla, Y.; Kumar, P.; Gupta, K.C. Curcumin loaded selenium nanoparticles synergize the anticancer potential of doxorubicin contained in self-assembled, cell receptor targeted nanoparticles. Eur. J. Pharm. Biopharm. 2018, 130, 185-199. [CrossRef]

240. Guorgui, J.; Wang, R.; Mattheolabakis, G.; Mackenzie, G.G. Curcumin formulated in solid lipid nanoparticles has enhanced efficacy in Hodgkin's lymphoma in mice. Arch. Biochem. Biophys. 2018, 648, 12-19. [CrossRef]

241. Fathy Abd-Ellatef, G.E.; Gazzano, E.; Chirio, D.; Hamed, A.R.; Belisario, D.C.; Zuddas, C.; Peira, E.; Rolando, B.; Kopecka, J.; Assem Said Marie, M.; et al. Curcumin-Loaded Solid Lipid Nanoparticles Bypass P-Glycoprotein Mediated Doxorubicin Resistance in Triple Negative Breast Cancer Cells. Pharmaceutics 2020, 12, 96. [CrossRef]

242. Harini, L.; Srivastava, S.; Gnanakumar, G.P.; Karthikeyan, B.; Ross, C.; Krishnakumar, V.; Kannan, V.R.; Sundar, K.; Kathiresan, T. An ingenious non-spherical mesoporous silica nanoparticle cargo with curcumin induces mitochondria-mediated apoptosis in breast cancer (MCF-7) cells. Oncotarget 2019, 10, 1193-1208. [CrossRef] [PubMed]

Publisher's Note: MDPI stays neutral with regard to jurisdictional claims in published maps and institutional affiliations.

(C) 2020 by the authors. Licensee MDPI, Basel, Switzerland. This article is an open access article distributed under the terms and conditions of the Creative Commons Attribution (CC BY) license (http://creativecommons.org/licenses/by/4.0/). 